\title{
Solvent versus thermal treatment for glass recovery from end of life photovoltaic panels: environmental and economic assessment
}

Francesca Pagnanelli ${ }^{a, b}$, Emanuela Moscardini ${ }^{b}$, Pietro Altimari ${ }^{a, b}$, Flavia C. S. M. Padoan ${ }^{a}$, Thomas Abo Atia ${ }^{a}$, Francesca Beolchini ${ }^{b, c}$ Alessia Amatoc ${ }^{c}$ Luigi Toro ${ }^{b}$

\author{
${ }^{\text {a }}$ Department of Chemistry, Sapienza University of Rome, P.le a. Moro 5, 00185 Rome, IT

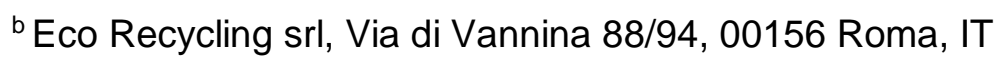 \\ ${ }^{c}$ Department of Life and Environmental Sciences, Università Politecnica delle Marche, Via Brecce \\ Bianche, Ancona, Italy
}

Corresponding author: F.C.S.M Padoan phone: +39 064991333 email address: flaviacarla.padoan@uniroma1.it

\begin{abstract}
End of life photovoltaic panels of different technologies (poly crystalline $\mathrm{Si}$, amorphous $\mathrm{Si}$, and CdTe) were treated mechanically in pilot scale by single shaft shredder minimizing the production of fine fractions below $0.4 \mathrm{~mm} \quad(<18 \%$ weight). Grounded material was sieved giving: an intermediate fraction $(0.4-1 \mathrm{~mm})$ of directly recoverable glass $(18 \%$ weight); a coarse fraction (which should be further treated for encapsulant removal), and fine fractions of low-value glass $(18 \%)$, which can be treated by leaching for the removal of metal impurities. Encapsulant removal from coarse fraction was successfully performed by solvent treatment using cyclohexane at $50^{\circ} \mathrm{C}$ for $1 \mathrm{~h}$ giving high-grade glass (52\% weight), which can be reused for panel production. Experimental results of solvent treatment were compared with those from thermal treatment by economic analysis and Life Cycle Assessment, denoting in both cases the advantages of solvent treatment in recovering high-value glass.
\end{abstract}

Keywords: recycling, photovoltaic panel, solvent treatment, thermal treatment, LCA 


\section{Highlights}

- Panel shredding was performed minimizing the fine fractions ( $<18 \%$ weight).

- In solvent route (cyclohexane at $50^{\circ}$ for $1 \mathrm{~h}$ ) high-value glass was recycled (52\% weight).

- Process analysis of solvent route (3,000 ton/y potentiality) gave PBT of 5-8.6 y.

- LCA of solvent route gave positive impacts due to high-grade glass recovery.

\section{INTRODUCTION}

Photovoltaic panels (PVP) are the emerging technology in renewable energy production with $42 \%$ EU market share in 2015 corresponding to an installed power of $97.6 \mathrm{GW}$ (SolarPower Europe, 2017).

According to this expansion, issues regarding the treatment of end of life panels guided the promotion of take back policies and recycling strategies: EU included PVP as wastes of electric and electronic equipment (Directive 2012/19/EU), and established minimum targets for collection (65\%), recycling (80\%), and recovery $(85 \%)$.

PVP on the market are highly heterogeneous including different technologies such as Si-based (monocrystalline, polycrystalline, and amorphous types), CdTe, and innovative types (such as CIS and CIGS) (IRENA, 2016). Among these different technologies Si crystalline is the dominating one (95\% in 2017) (Fraunofer Institute, 2017) mainly because of the highest efficiency and the cost reduction in manufacturing (Sopian et al., 2017).

The amount of end of life PVP to be treated in the future can be estimated considering past installation data and market forecast. Simulations of PVP waste projections were reported assuming a Weibull distribution function for panel lifetime (Padoan et al., 2019) according t two scenarios: breakthrough scenario in which $0.25 \%$ of panels are returned before warranty time (usually 5 years); slow progress scenario in which 4\% returned before warranty time. These simulations denoted that in EU a maximum of waste production of 1.4 Mton/y will occur in 2041 (1.6 Mton/y maximum is expected in 2044 using the breakthrough scenario). In Italy, about 220,000 ton/y are expected as maximum waste production in 2040 (or 280,000 ton/year in 2044 for breakthrough scenario). Comparing these simulations with those already reported by Paiano 
(2015) assuming fixed lifetime for panels (25 years), a high reduction of the maximum expected amount per year can be observed: with fixed lifetime Paiano predicted in Italy a maximum of about one million ton in 2036. The correct estimation of these figures is important for assessing the economic feasibility of developed processes, strictly depending on the adopted scale, which in turn cannot be larger than the expected waste collection. Then, considering the hypothesis that panel lifetime is distributed and not fixed, more realistic amount of wastes collected every year can be estimated. According to such simulations about 3,000 ton of waste panels should be collected in Italy in $2025,27,000$ ton in 2030 , and 100,000 in 2035 . Then this range of potentiality should be used for assessing feasibility in the next years in Italy.

Literature survey about photovoltaic panel recycling evidenced a variety of processes for the treatment of these wastes, all aiming to the liberation of the different panel constituents (glass, Si cells, and metals) from the encapsulant (Ethylene Vinyl Acetate, EVA).

Even though some innovative approach have been recently proposed (Akimoto et al., 2018; Duflou et al., 2018), two main methods have been adopted in order to liberated the different components: thermal treatment and solvent treatment; both treatments can be used with integer panels or crushed panels obtained after mechanical treatment.

Thermal treatment of panels was widely described in the literature reporting data about the effect of temperature and time on the EVA degradation and the analysis of the gaseous phase (Frisson et al., 2000; Wang et al., 2012; Weinfurtner, 1996). In particular, Dias et al. 2017 observed that $99 \%$ degradation of polymer was obtained after $30 \mathrm{~min}$ at $500^{\circ} \mathrm{C}$, with degradation continuing slowly for larger times. Kang et al., (2012) observed that complete removal of EVA was obtained after treatment at $600^{\circ} \mathrm{C}$ for $1 \mathrm{~h}$.

Solvent treatment is less diffused especially because of the lower kinetics with respect to thermal treatment, and the use of toxic, flammable, and expensive solvents.

Doi et al., 2001 investigated different solvents at 80 (Lacquer thinner, Acetone, Toluene, Petroleum benzene, Ethanol, Isopropanol, Methyl ethyl Ketone, Methyl isobutyl Ketone, Tetrahydrofuran, Ethylene glycol, Trichloroethylene, Glycerine) for PVP treatment and cell recovery 
and found the best results using trichloroethylene for 10 days. Prado et al., (2017) found that cell removal was obtained using isopropanol for 2 days at room temperature.

The recycling targets for photovoltaic panels can be glass, Si cells and metals, such as Al (frames), $\mathrm{Cu}$ (metallic filaments), and Ag present in Si crystalline cells, or In, Ga, Se in CIS and CIGS cells. According to the patent survey reported in IEA (2018), 68\% percent of the world recycling patents for photovoltaic panels target semiconductor materials in the cells, and only $32 \%$ glass, probably due to the scarcity of conductor materials.

Literature survey denoted the same trend with works aiming to the recovery of silicon (Doi et al., 2011; Doni and Dughiero, 2012; Yi et al., 2014; Jung et al., 2016), silver (Dias et al., 2016; Jung et al., 2016), gallium, selenium, and indium (Kushiya et al., 2003; Gustafsson et al., 2014; Gustafsson et al., 2014).

Nevertheless, the content of such metals have been dramatically reduced during years according to the need of decreasing the production cost of panels.

In early 2000 , Si wafer was about $50 \%$ of the cost of panel manufacturing (Goetzberger et al., 2003) but now this impact has greatly reduced because of the diminished content of Si in panels (due to cell thickness reduction from 400 to $200 \mu \mathrm{m}$ )(Sopian et., al 2013), and to the decrease of Si price on the market (from 3 USD in 2010 to 0.5 USD in 2017 mainly due to overproduction) (IRENA, 2017). Both these aspects reduce the possibility of fixing $\mathrm{Si}$ as recycling target for sustainable process development.

Even in the case of $\mathrm{Ag}$, the content of this metal in panels has been gradually reduced during time from $0.2-0.22 \%$ weight in 2000 to $0.002-0.02 \%$ in 2025 (Peeters et al., 2017).

It should be also noted that focusing on metals cannot allow achieving the ambitious EU recycling targets $(80 \%)$ being glass the main component of panels (69-75\%), while Si represents about $3 \%$ of the weight of the panel mass (Dias and Veit, 2019).

Surprisingly, even though glass is the main constituent of panels, it is not specifically addressed or characterized in the literature works regarding photovoltaic panels recycling. The final use of the recycling glass is not investigated at all: only some works (Hao et al., 2012; Lin et at., 2012) 
reported the addition of fine glass fractions (obtained by crushing and sorting of photovoltaic panels) in the formulation of building materials such as high density matrixes for civil engineering and glass-ceramics. This means recycling solar glass of panels as low-grade product against the priority of promoting high-quality recovery operations defined by the European Committee for Electrotechnical Standardization for photovoltaic panels (CENELEC EN50625-2-4).

Another limit of literature works is the representativeness of wastes used: generally one unit of panel of one selected type is used for dedicated experiments after manual cutting of fragments. This approach greatly underestimates the effect of heterogeneity of panels both in the same type (due to different manufacturing) and among the different types (Si, CdTe, CIS and CIGS).

Previous works of this research group addressed mechanical and thermal treatment of different panel technologies reporting detailed chemical and structural characterization of the obtained fractions (Pagnanelli et al., 2017).

In this work, a novel solvent treatment for the recycling of panels of different types is reported and compared with previous data of thermal treatment considering both economic figures and environmental impacts.

The first novelty aspect of this work is the solvent, cyclohexane, which was used for the first time in the literature as chemical for the treatment of photovoltaic panels of different types.

The second novelty aspect is using waste fractions from pilot scale mechanical treatment of different type of panels, while literature results are generally obtained manually dismantling one single panel of a specific type: working with crushed samples from pilot equipment give strength to the results obtained by solvent treatment.

Another element of novelty is addressing the high value reuse of glass and then elaborating mass balances of the process in line with EU targets and CENELEC priority for recycling rate.

Finally, considering the modern relevance of the environmental issue, processes were compared in terms of impacts on the environment. In this regard, the life cycle assessment (LCA) tool has been widely applied to compare the sustainability and environmental performance of technologies applied in the management of WEEE (Amato et al., 2017; Bigum et al., 2012; lannicelli-Zubiani et 
al., 2016; Menikpura et al., 2014). More in detail, as concerns the photovoltaic panels, literature has mainly focused on the electricity generation (Desideri et al., 2012; Gerbinet et al., 2014; Kim et al., 2014; Peng et al., 2013; Sherwani et al., 2010; Stoppato, 2008). Conversely management of end of life panels has been addressed only very recently (Giacchetta et al., 2013; Latunussa et al., 2016; Raugei et al., 2012; Rocchetti and Beolchini, 2015). In this context, there is the need to improve the available scientific literature with case studies potentially feasible in large scale recycling plants.

\section{MATERIALS AND METHODS}

\subsection{Experimental section: physical pretreatment and solvent treatment}

Three types of photovoltaic panels were used in this work: polycrystalline silicon PV module (Mage Solar Plus 230/PE, fabrication year: 2011), amorphous silicon PV module (Sharp NA-E135L5, fabrication year: 2013), CdTe PV module (First Solar FS 380, fabrication year: 2011).

The sequence of operations included in the recycling process was reported in the block diagram of Figure 1.

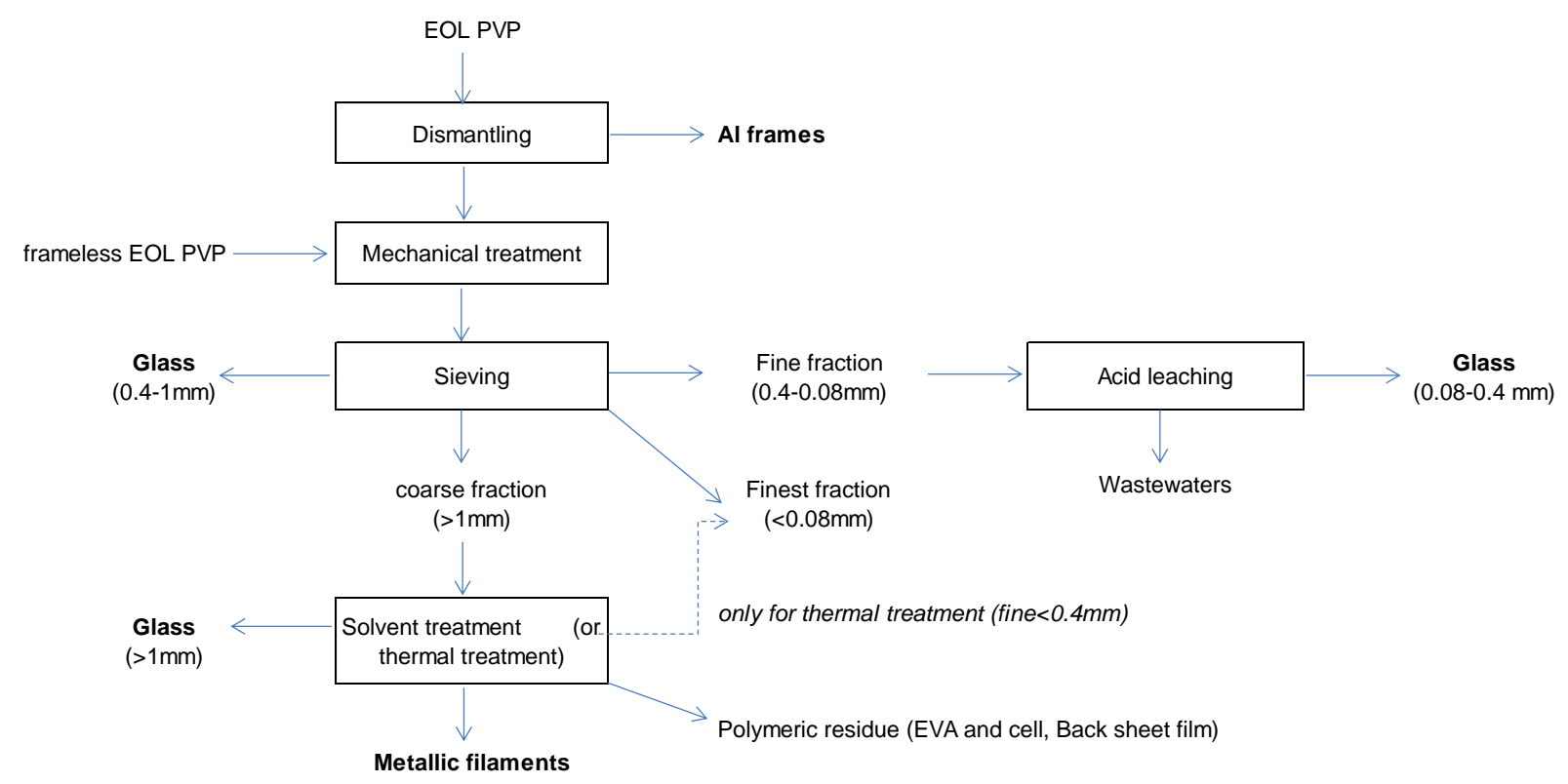

Figure 1: Block diagrams describing the process for treating end of life photovoltaic panels (EOL PVP). 
Generally, Si crystalline modules have an external frame of Al, while CdTe and amorphous Si panels are frameless due to their reduced weight. Before shredding, EOL PVP with frames were manually disassembled in order to recover Al frames, while frameless PVP can be directly fed to the mechanical treatment.

Crushing operations were carried out using a single shaft shredder (Guidetti Idt) with an undersieve of $20 \mathrm{~mm}$. After crushing, sieving was performed separating four fractions: a coarse fraction $(>1 \mathrm{~mm})$, an intermediate fraction $(0.4-1 \mathrm{~mm})$, a fine fraction $(0.08-0.4 \mathrm{~mm})$, and a finest fraction $(<0.08 \mathrm{~mm})$.

The coarse fraction was treated by solvent treatment using cyclohexane (chemical grade reagent Sigma Aldrich) with a solid/liquid ratio equal to $0.2 \mathrm{~g}$ of coarse fraction per $\mathrm{ml}$ of solvent for $1 \mathrm{~h}$ with and without magnetic stirring at different temperatures in the range $40-60^{\circ} \mathrm{C}$.

After usage, cyclohexane is recovered by solid/liquid separation (and after filtration reused for treating the coarse fraction) and by evaporation and condensation from EVA fragments.

Fractions $<0.08$ and $0.08-0.4 \mathrm{~mm}$ were characterized for their metal content by mineralization. Fractions of Si-based panels (polycrystalline and amorphous) were joined together before characterization. Mineralization was performed using $1 \mathrm{~g}$ of sample treated with $3 \mathrm{ml} \mathrm{HNO}_{3}$ (69\%ww by Sigma Aldrich), $9 \mathrm{ml} \mathrm{HCl}$ (37\%ww by Sigma Aldrich) and $0.6 \mathrm{ml} \mathrm{H}_{2} \mathrm{O}_{2}$ (36\%ww by Sigma Aldrich) in microwave digester (ETHOS 900, Milestone) under the following conditions:

- step 1: 10 minutes from room temperature up to $220^{\circ} \mathrm{C}$ at $1,000 \mathrm{~W}$

- step 2: 20 minutes at $220^{\circ} \mathrm{C}$ at $1,000 \mathrm{~W}$

After filtration liquid solution was analysed by Atomic Absorption Spectrophotometer (AAS, contrAA (B) 300 - Analytik Jena AG) equipped with a Xenon short arc lamp as radiation source and with a flame atomizer fed with a mixture of $\mathrm{C}_{2} \mathrm{H}_{2}$ and air. Multistandard solution (Merk Millipore $1000 \mathrm{mg} / \mathrm{L}$ $\mathrm{HNO}_{3}$ ) was used for calibration and each metal was determined according to a selected wavelength $(\mathrm{Fe}=248.33 \mathrm{~nm}, \mathrm{Zn}=213.86 \mathrm{~nm}, \mathrm{Cu}=324.75 \mathrm{~nm}, \mathrm{Sn}=224.61 \mathrm{~nm}, \mathrm{Ag}=328.07 \mathrm{~nm}$, $\mathrm{Cd}=228.80 \mathrm{~nm}, \mathrm{Te}=214.28 \mathrm{~nm}$ ) reading three replicates for each metal. 
Leaching of fine fractions $(0.08-0.4 \mathrm{~mm})$ was performed using $2 \mathrm{M}$ solution of $\mathrm{H}_{2} \mathrm{SO}_{4}(96 \%$ ww by Sigma Aldrich) at $60^{\circ} \mathrm{C}$ for $3 \mathrm{~h}$ under magnetic stirring with a solid/liquid ratio of 0.2 . Metal extractions were determined measuring the metal concentration in solution by AAS.

\subsection{Process simulations}

Process simulations were performed considering two alternative process routes for coarse fraction treatment: solvent route as detailed before and thermal treatment at $650^{\circ} \mathrm{C}$ for $1 \mathrm{~h}$ as reported in a previous work (Pagnanelli et al., 2017). Simulated processes included mechanical treatment, sieving, solvent (or thermal) treatment of coarse fraction, leaching of fine fractions.

In Figure 1S of Supplementary Material, the detailed flow diagrams for both options were reported. Mass balances were determined according to experimental tests at pilot (mechanical treatment and thermal treatment) and lab scale (solvent treatment).

Process simulations were performed with two potentialities, 3,000 ton/y and 30,000 ton/y.

Plant costs for 3,000 ton/year potentiality were estimated by dedicated process design (not reported here) and correspond to $2.5 \mathrm{M} €$. Plant costs for 30,000 ton/y potentiality were estimated with a scale law $C_{x}=C_{3000}{ }^{*}\left(P_{x} / P_{3000}\right)^{0.7}$, where $C_{x}$ is the plant cost for potentiality $P_{x}$, and $C_{3000}$ is the plant cost for treating 3,000 ton/y.

Chemical costs for $\mathrm{H}_{2} \mathrm{SO}_{4} 96 \%(0.5 € / \mathrm{Kg}), \mathrm{H}_{2} \mathrm{O}_{2} 30 \%(0.45 € / \mathrm{Kg})$, cyclohexane $(1 € / \mathrm{Kg})$, energy costs $(0.07 € / \mathrm{KWh})$, wastewater treatment cost $(0.14 € / \mathrm{Kg})$, and leach liquor recycling (with $1 \%$ make-up) were determined according to demonstration activities performed at pilot scale by Eco Recycling within Hydroweee Demo (http://cordis.europa.eu/result/rcn/158626_en.html) and Photolife project (www.photolifeproject.eu).

Output products in process simulations were:

- high-grade glass from solvent treatment of coarse fraction (Glass $>1 \mathrm{~mm}$ ),

- low-grade glass as fine fractions from sieving (Glass $0.4-1 \mathrm{~mm}$ ),

- low grade glass as fine fractions after leaching (Glass $0.08-0.4 \mathrm{~mm}$ ),

- low-grade glass as coarse fraction from thermal treatment (Glass $>1 \mathrm{~mm}$ ),

- Al scraps from the frames, 
- Cu-bearing metallic filaments

Low-grade glass selling price was fixed at $0.05 € / \mathrm{Kg}$ (Bio Intelligence Service, 2011); the prices of $\mathrm{Al}$ frames and $\mathrm{Cu}$ filaments were set as 0.7 and $2 € / \mathrm{Kg}$, respectively (https://www.capitalscrapmetal.com/prices/).

Simulations were performed for different combinations of the process inputs estimating the Pay Back Time, which corresponds to the time (expressed in years) needed to recover the initial in investment.

\subsection{Life cycle assessment}

The overall life of a photovoltaic panel includes the main phases of production, use and the final collection, followed by the treatment for the recovery of valuable materials (Figure S2). Considering the target of the present work, the system boundaries of LCA included only the end-of-life management (dotted line in Figure S2), comparing the two optimized technologies: the solvent (scenario 1) vs. the thermal (scenario 2) process. The treatment of $1,000 \mathrm{~kg}$ of end-of-life PV panels was chosen as functional unit.

The thinkstep GaBi software-System and Database for Life Cycle Engineering (compilation 7.3.3.153; DB version 6.115) was used for the assessment. The midpoint impacts of processes were evaluated following the International Reference life cycle data system (ILCD) recommendation for the life cycle impact assessment (LCIA) (ILCD, 2010). Normalization and weighting were carried out according to the Product Environmental Footprint (PEF) method (Manfredi et al., 2012). The method described by Castellani et al. 2016 was chosen for the weighting, considering a European scale, in the perspective of the process implementation within facilities in this area (Castellani et al., 2016; Zampori et al., 2016). The categories showed for the characterization were selected on the basis of their relevance obtained by a whole data normalization (higher than $3 \%$ of the whole impact), excluding the results relative to ionizing radiation, ecosystems since the method is not considered mature by ILCD Recommendation. All the data were present in the Gabi Professional Database, except those relative to: glass cullet and solar glass. These values were acquired from Ecoinvent 2.0 Database and then normalized and 
weighted using the same method as the other processes. Input and output data for the inventory analysis are summarized in Table S1 in Supplemental material. As concerns the emissions of the thermal treatment, the average values were extrapolated from Tammaro et al. (2015) that studied the metals in gas phases produced by the heating of crystalline panel in a furnace up to $600^{\circ} \mathrm{C}$. On the other hand, the degraded EVA film, separated during the solvent treatment, was disposed in landfilling sites, as plastic waste (Valenzano et al., 2000).

As concerns the positive effects due to the recovery of secondary raw materials, they were quantified as credits, i.e. as avoided impacts for the primary production, and reported as negative values. In this regard, some assumptions were necessary in order to complete the evaluation. In particular, the metal filaments recovered from mechanical crushing were considered completely composed of copper (the main element in agreement with Azeumo et al., 2019), and the Tedlar production process was substituted by the polyvinyl chloride one, considering that Tedlar is a polyvinilfluoride, for the lack in the reference databases. Credits due to the glass recovered by the two different options showed different values, since the solar cullet from solvent treatment (scenario 1) has superior properties than the residue from thermal treatment (scenario 2), as confirmed the material characterization which proved the possibility to use the first product for the manufacture of new panels. Nevertheless, to quantify the possible avoided environmental load connected with the material recovery, the data per kg of glass from the Econinvent database, was halved. This assumption ensures a conservative condition, since the literature reports an impact reduction higher than $50 \%$ achieved by the glass recycling (Butler and Hooper, 2011; Larsen et al., 2009). The possibility of aluminium frame exploitation was included within the system boundaries to further emphasize the intrinsic value of the end of life photovoltaic panel. Despite it is not recommended by the attributional LCA method, the comparison between the environmental load of recycling and the credits associated to the recovered fractions highlights the process sustainability. Furthermore, an additional assessment was carried out specifically to the solvent treatment, where the recycled glass can be reused for new panel manufacturing. Such assessment included a comparison with the primary panel production in terms of carbon footprint, based on literature data 
which report average impacts of $19 \mathrm{~kg} \mathrm{CO}$-Equiv./kg of panel (poly crystalline $\mathrm{Si}$ ), $20 \mathrm{~kg} \mathrm{CO}$ 2- $^{-}$ Equiv./kg of panel (amorphous Si) and 4 kg CO -Equiv./kg of panel (CdTe) (Ito et al., 2010; Kim et al., 2014; Leccisi et al., 2016; Sherwani et al., 2010; Stamford and Azapagic, 2018; Xie et al., 2018). In this case the environmental credit was added at the point of substitution.

\section{RESULTS AND DISCUSSION}

\subsection{Experimental results from pilot and lab scale}

The described processes included mechanical and chemical operations for the treatment of the fractions obtained from end of life panels (Figure 1). The same operations were performed using panels of different types (polycrystalline, amorphous and CdTe) in order to assess the performance of the process for different input technologies.

In Figure 2, pictures of sieved fractions obtained for polycrystalline Si panel were reported. Four fractions were separated: a coarse fraction $(>1 \mathrm{~mm})$ (Figure $2 \mathrm{a})$ requiring further treatment for multi-layered fragment detachment, an intermediate fraction $(0.4-1 \mathrm{~mm}$ ) (Figure $2 \mathrm{~b}$ ), which is made of directly recoverable glass, and two fine fractions $(0.08-0.4 \mathrm{~mm}$ and $<0.08 \mathrm{~mm}$ ) (Figure $2 \mathrm{c}$ showing their mixture).
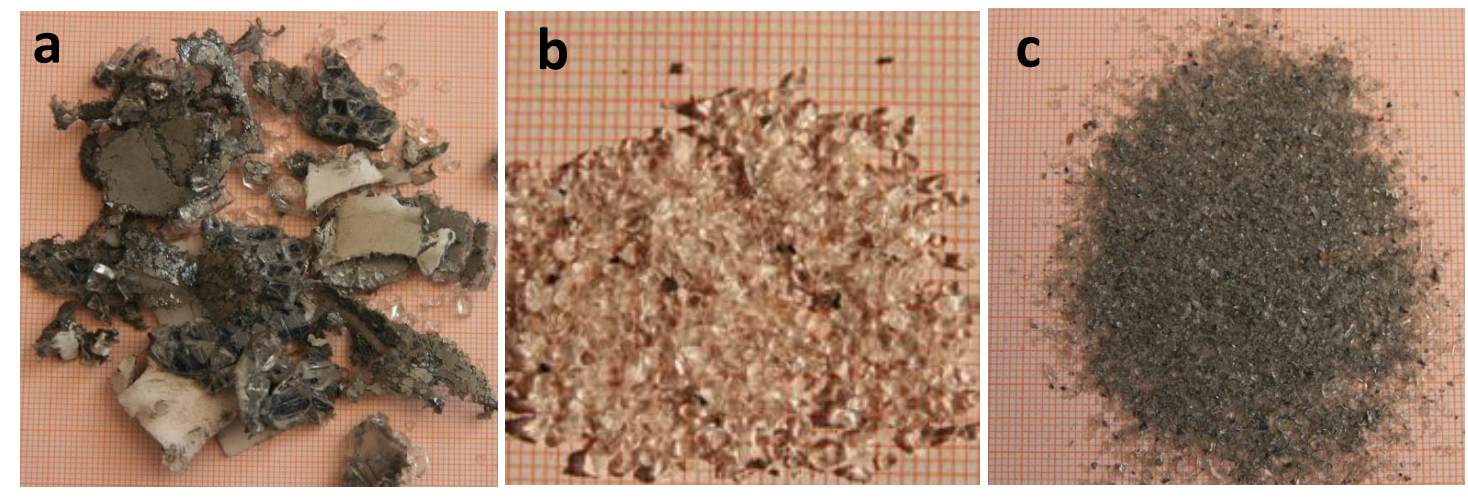

Figure 2: Ground materials from the mechanical treatment and fractions separated (a: coarse fraction; b: glass; c: fine fractions).

Considering the weight of the fractions obtained by shredding very similar results were obtained for the three photovoltaic technologies (Figure 3). The following mean values obtained as \% of weight of the material fed to the shredder: $18 \pm 2 \%$ as directly recoverable glass (intermediate fraction 0.4 - 
$1 \mathrm{~mm}) ; 63 \pm 3 \%$ as coarse fraction, $16 \pm 1 \%$ as fine fraction $(0.08-0.4 \mathrm{~mm})$, and $2.1 \pm 0.1 \%$ as finest fraction $(<0.08 \mathrm{~mm})$.

Previous experimental tests using manual triple crushing operations in two-blade rotors crusher without any controlling sieve gave similar results (Pagnanelli et al. 2017). In these past tests, controlling sieving was avoided in order to reduce fine fraction formation and the output of a crushing cycle is manually re-fed in the crusher for a successive cycle of crushing.

Experimental results reported in this work showed that single shaft shredder equipped with undersieve allowed automatic treatment of panels avoiding the manual re-feed and keeping fine fraction $(<0.4 \mathrm{~mm})$ below $18 \%$ weight.

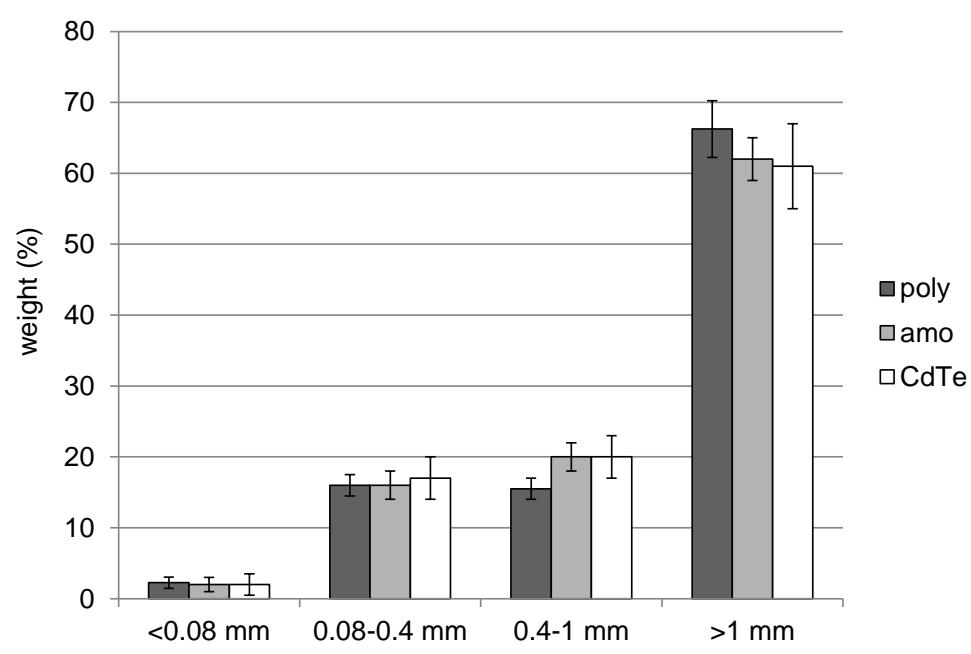

Figure 3: Particle size distribution as weight \% of the frameless panels after shredding (poly: Polycrystalline Si panel; amo: amorphous Si panel; CdTe: CdTe panel).

Coarse fractions required further treatment in order to separate glass from other components (EVA, cell and back sheet film).

Material detachment from coarse fractions was performed by using cyclohexane as solvent, and changing both temperature and stirring conditions (Figure 4).

After solvent treatment different fractions can be recovered: glass, EVA with adherent cell material, back sheet film (generally Tedlar), and metallic filaments of copper (Figure 5). 
Experimental tests showed the effect of operating conditions on the weight fraction of the separated components (glass, EVA with adherent cell material, back sheet film, metallic filaments), and on the degree of separation defined as the weight of all separated components divided the initial weight of coarse fraction used in the test.

As for the effect of the investigated factors (Figure 4), it is possible to see that using a fixed treatment time (1h) a complete separation of materials can be obtained at $60^{\circ} \mathrm{C}$ without stirring, while the same result can be obtained at $50^{\circ} \mathrm{C}$ under magnetic stirring.

As for the mechanism of detachment of cyclohexane, it could be the same of other solvents used for cell recovery including partial dissolution and swelling of the polymer (Doi et al., 2001). In the investigated conditions, only a partial dissolution of EVA occurs, and after treatment EVA fragments remain almost intact with pieces of cell material still adherent (Figure 5C).

According to the dissolution/swelling mechanism, the degree of separation of the different materials results facilitated in conditions promoting solvent transport inside EVA matrix, thus swelling it and making it loosing adherence with glass and back sheet film. In fact, both temperature increase and mixing improve the kinetic of solvent penetration through EVA matrix thus explaining the obtained results.

The polymeric residue from solvent treatment is made up of EVA fragments, black parts of cells still adhering to EVA, and back sheet film of Tedlar. Preliminary characterization of black cell fragments by XRF (experimental data not reported here) denoted the presence of metals typically contained in PVP cells (such as Si and Ag) and acid digestion of the polymeric residue denoted $\mathrm{Ag}$ concentration up to $10 \mathrm{mg} / \mathrm{g}$ (experimental data not reported here).

The best condition chosen for environmental and economic analysis was $50^{\circ} \mathrm{C}$ under mixing.

Glass fraction obtained from CdTe type was reported in Figure S3 of Supplementary Material denoting the same efficacy of solvent treatment in these conditions in detaching glass from this kind of panels.

Thermal treatment can be used as alternative to solvent treatment for coarse fraction (Pagnanelli et al., 2017). Previous results evidenced that thermal treatment determined the detachment of 
multi-layered fragments thus releasing glass and a black fine residue of cell elements, also partially adhering to recovered glass. In Figure S4 of Supplementary Material, glass obtained by thermal treatment is compared with that from solvent treatment denoting the presence of a brown coating on the first one due carbon and metal residues. The metallic content in the coarse fraction obtained by thermal treatment was estimated by X-Ray Fluorescence analysis (XRF) denoting the presence of metals such as $0.3 \%$ of $\mathrm{Cu}, 0.2 \%$ of $\mathrm{Zn}, 0.12 \%$ of $\mathrm{Sn}$, and $0.35 \%$ of $\mathrm{Fe}$ (Table $\mathrm{S} 2$ in Supplementary Material).

In order to assess the relevance of such impurities, typical composition of glasses used for photovoltaic panels was considered. Glass used for photovoltaic panels is generally soda-lime glass, whose chemical composition is defined in the German DIN standard EN572-1 according to the following: $69-74 \%$ as $\mathrm{SiO}_{2}, 10-16 \%$ as $\mathrm{Na}_{2} \mathrm{O}, 5-14 \%$ as $\mathrm{CaO}, 0-6 \%$ as $\mathrm{MgO}, 0-3 \%$ as $\mathrm{Al}_{2} \mathrm{O}_{3}$, and $0-5 \%$ as $\mathrm{Fe}_{2} \mathrm{O}_{3}$ and $\mathrm{K}_{2} \mathrm{O}$. Typical composition of soda-lime glasses used for photovoltaic applications was reported as: $72 \% \mathrm{SiO}_{2}, 14 \% \mathrm{Na}_{2} \mathrm{O}, 8 \% \mathrm{CaO}, 4 \% \mathrm{MgO}, 1.3 \% \mathrm{Al}_{2} \mathrm{O}_{3}$, and $0.7 \%$ as others $\left(\mathrm{Fe}_{2} \mathrm{O}_{3}\right.$ and $\left.\mathrm{K}_{2} \mathrm{O}\right)$ (Blieske and Stollwerck, 2013). Among impurities, attention is given to positive metal ions in the glass matrix, whose diffusion seems to be responsible for the Potential Induced Degradation in photovoltaic installations (Koch et al., 2012). Considering the composition of high-value glass recovered from solvent treatment as obtained by XRF analysis $\left(72.2 \% \mathrm{SiO}_{2}\right.$, 13.9\% $\mathrm{Na}_{2} \mathrm{O}, 9.5 \% \mathrm{CaO}, 2.5 \% \mathrm{MgO}, 1.2 \% \mathrm{Al}_{2} \mathrm{O}_{3}$ ) (Table S2), it perfectly fitted with the typical composition reported in the literature presenting a content of other components $\left(\right.$ as $\mathrm{Fe}_{2} \mathrm{O}_{3}, \mathrm{~K}_{2} \mathrm{O}$ and $\mathrm{Sb}_{2} \mathrm{O}_{3}$ ) equal to $0.42 \%$. On the other side, thermal glass presented a significant amount of metal impurities giving $2.5 \%$ of other components (as oxides). This evaluation evidenced that metal impurities in thermal glass exceeded the typical content of other elements in glass used for photovoltaic applications. 


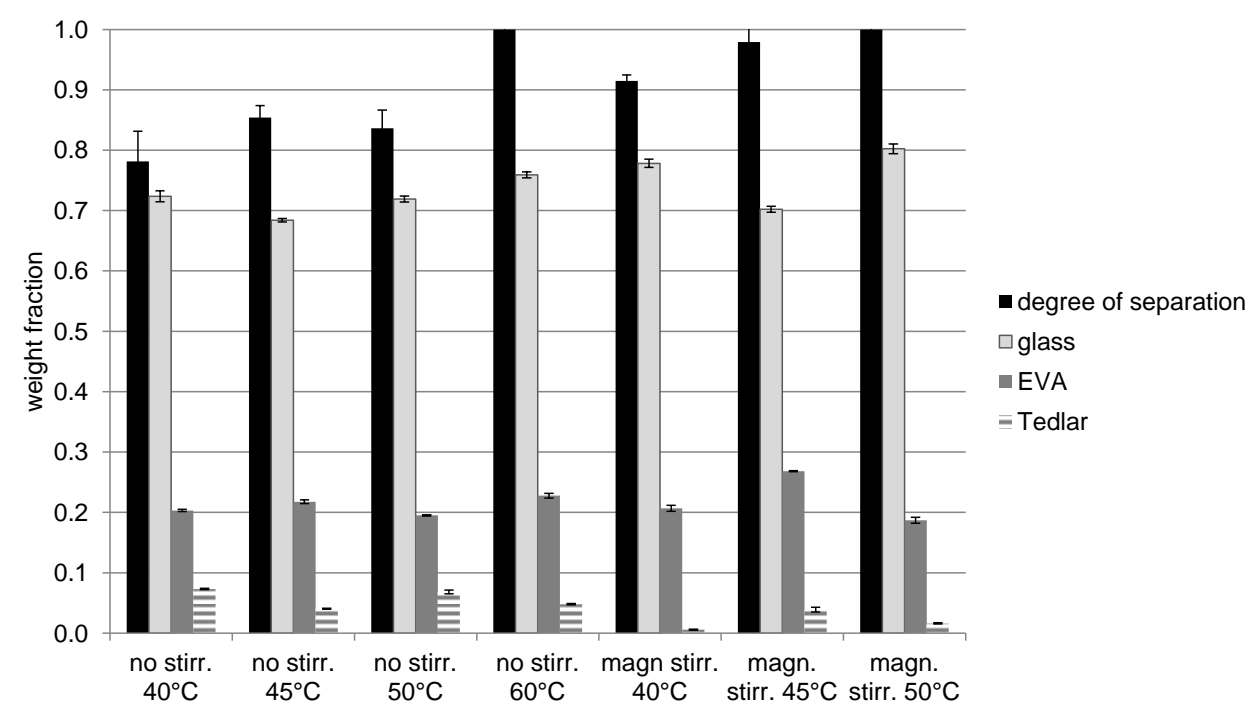

Figure 4: Degree of separation, and weight fraction of the different materials obtained by solvent treatment without stirring (no stirr.) and under magnetic stirring (magn. stirr.) at different temperatures using the coarse fractions obtained by mechanical treatment.

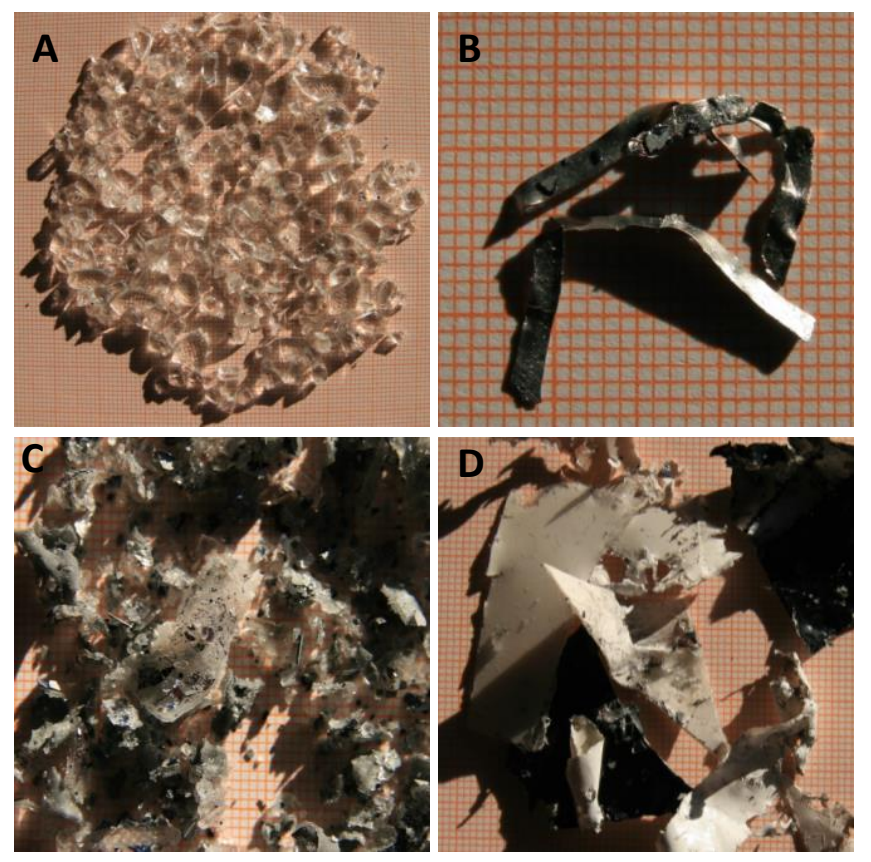

Figure 5: Recovered materials from solvent treatment of coarse fractions of polycrystalline modules $\left(50^{\circ} \mathrm{C}\right.$ under stirring): A: glass; B: metallic filaments; C: EVA plus cell materials; D: back sheet film. 
Characterization of fine fractions emerging from mechanical treatment of Si-based panels and CdTe panels denoted the predominance of $\mathrm{Fe}, \mathrm{Zn}, \mathrm{Al}$ as low value metal impurities for both types of panels (Table 1). In these fractions, also metals that are characteristic of the panel type can be found: Sn and Ag for Si-panels, and Cd and Te for CdTe-panels.

It should be noted that, due to the specific characteristics of the grinding apparatus, a reduced amount of fine fractions is produced in this process (18\%) leaving the cells and their metals adhering to the EVA fragments (Figure 5C) instead of producing metal-rich fine glass fractions.

Accordingly, metal concentration in the fine fraction is low $(<1 \mathrm{mg} / \mathrm{g})$.

In the analysis reported in this work, fine fractions were considered as low-grade glass, which could be used (according to current practice) directly in cement preparation or for the production of building materials (Hao et al., 2012; Lin et at., 2012). Information about the tolerable amount of metals in waste glass from PVP in such material building formulation was not available. Nevertheless, metal impurities in fine fractions can be easily eliminated/reduced by acid leaching.

\begin{tabular}{lcllllllll}
\hline Panel & $\begin{array}{c}\text { Fraction } \\
(\mathrm{mm})\end{array}$ & $\mathrm{Fe}$ & $\mathrm{Zn}$ & $\mathrm{Al}$ & $\mathrm{Cu}$ & $\mathrm{Sn}$ & $\mathrm{Ag}$ & $\mathrm{Cd}$ & $\mathrm{Te}$ \\
& & & & & & & & & \\
\hline $\mathrm{Si}$ & $0.08-0.4$ & $5.2 \pm 0.1$ & $0.21 \pm 0.04$ & $3.00 \pm 0.04$ & $0.6 \pm 0.1$ & $0.22 \pm 0.01$ & $0.01 \pm 0.01$ & - & \\
$\mathrm{Si}$ & $<0.08$ & $11 \pm 1$ & $8.2 \pm 0.9$ & $5 \pm 2$ & $1.2 \pm 0.3$ & $0.32 \pm 0.03$ & $0.01 \pm 0.01$ & - & - \\
$\mathrm{CdTe}$ & $0.08-0.4$ & $1.2 \pm 0.1$ & $1.2 \pm 0.1$ & $0.1 \pm 0.1$ & $0.03 \pm 0.01$ & - & - & $0.8 \pm 0.1$ & $0.01 \pm 0.01$ \\
$\mathrm{CdTe}$ & $<0.08$ & $11 \pm 2$ & $9 \pm 2$ & $3.6 \pm 0.5$ & $0.20 \pm 0.04$ & - & - & $1.2 \pm 0.1$ & $0.6 \pm 0.1$ \\
\hline
\end{tabular}

Table 1: Metal content $(\mathrm{mg} / \mathrm{g})$ in the fractions smaller than $0.4 \mathrm{~mm}$ for panels based on $\mathrm{Si}$ technology (polycrystalline and amorphous) and CdTe technology.

Preliminary tests of leaching of $0.08-0.4 \mathrm{~mm}$ fraction were performed to such aim. In tested conditions, the complete leaching of $\mathrm{Zn}$, the removal of $80 \%$ of $\mathrm{Al}$ and of the $70 \%$ of $\mathrm{Fe}$ were achieved giving final concentrations of $\mathrm{Al}$ and $\mathrm{Fe}$ of 0.6 and $1.5 \mathrm{mg} / \mathrm{g}$, respectively. These 
preliminary results evidenced the possibility of cleaning these fractions from the main metals in mild conditions.

\subsection{Mass balances and estimates of energy consumption}

Mass balances and estimates of energy consumption related to the treatment of polycrystalline Si, amorphous Si and CdTe panels were reported in Table 2.

Glass was directly recovered as intermediate fraction after shredding (glass $0.4-1 \mathrm{~mm}$ ), after solvent treatment (or thermal treatment) of the coarse fraction (glass $>1 \mathrm{~mm}$ ), and after the acid leaching of the fine fraction (glass $0.08-0.4 \mathrm{~mm}$ ).

According to these balances, the average weight of glass recycled was $87 \%$ for solvent treatment and $85 \%$ for thermal treatment. Other fractions which can be directly recycled are Al frames (10\%) when present, and metallic contacts $(0.07 \%)$.

The recycling rate for the solvent treatment and thermal treatment are 89 and $88 \%$, respectively, satisfying the EU target for recycling of matter (80\%). 


\begin{tabular}{|c|c|c|c|c|c|c|}
\hline \multirow{2}{*}{ Material (kg) } & \multicolumn{3}{|c|}{ Thermal treatment } & \multicolumn{3}{|c|}{ Solvent treatment } \\
\hline & Poly & Amo & CdTe & Poly & Amo & $\mathrm{CdTe}$ \\
\hline Aluminium frames & 100 & 0 & 0 & 100 & 0 & 10 \\
\hline Glass (0.4-1 mm) & 138 & 198 & 198 & 138 & 198 & 198 \\
\hline Glass (>1mm) & 458 & 531 & 537 & 486 & 540 & 535 \\
\hline Glass $(0.08-0.4 \mathrm{~mm})$ & 143 & 175 & 168 & 143 & 175 & 168 \\
\hline Glass (tot) & 739 & 904 & 903 & 767 & 913 & 901 \\
\hline Metallic filaments (copper) & 7 & 8 & 7 & 7 & 8 & 7 \\
\hline EVA & - & - & - & 75 & 38 & 36 \\
\hline Tedlar & - & - & - & 21 & 20 & 25 \\
\hline Finest fraction $(<0.08 \mathrm{~mm})$ & 78 & 35 & 33 & 20 & 9 & 20 \\
\hline Weight loss (MT) & 9 & 10 & 10 & 9 & 10 & 10 \\
\hline Weight loss (TT) & 68 & 43 & 46 & - & - & - \\
\hline Weight loss (ST) & - & - & - & 1 & 2 & 1 \\
\hline $\begin{array}{l}\text { Energy for mechanical crushing } \\
\text { (kWh) }\end{array}$ & 27.5 & 27.5 & 27.5 & 27.5 & 27.5 & 27.5 \\
\hline $\begin{array}{l}\text { Energy for agitation in solvent } \\
\text { treatment }(\mathrm{kWh})\end{array}$ & - & - & - & 5.3 & 5.3 & 5.3 \\
\hline $\begin{array}{l}\text { Energy for heating in solvent } \\
\text { treatment }(\mathrm{kWh})\end{array}$ & - & - & - & 29 & 32 & 32 \\
\hline $\begin{array}{l}\text { Energy for drying EVA and recovering } \\
\text { cyclohexane in solvent treatment }\end{array}$ & & & & & & \\
\hline (kWh) & - & - & - & 10.6 & 10.6 & 10.6 \\
\hline $\begin{array}{l}\text { Energy for hydrometallurgical } \\
\text { treatment of the glass fraction }(0.08 \text { - } \\
0.4 \mathrm{~mm})(\mathrm{kWh})\end{array}$ & 23.5 & 30 & 28.8 & 23.5 & 30 & 28.8 \\
\hline Energy for thermal treatment (kWh) & 95.5 & 105.7 & 106.8 & - & - & - \\
\hline Overall energy consumption (kWh) & 146.5 & 163.2 & 163.1 & 95.9 & 105.4 & 104.2 \\
\hline
\end{tabular}

Table 2: Mass balances of the processes including mechanical treatment (MT) followed by solvent treatment $(\mathrm{ST})$ or thermal treatment $(\mathrm{TT})$ of the coarse fraction $(>1 \mathrm{~mm})$, and acid leaching of the fine fraction $(0.08-0.4 \mathrm{~mm})$ starting from $1,000 \mathrm{Kg}$ of input panels of different types (Poly: Polycrystalline Si panel; Amo: Amorphous Si panel; CdTe: CdTe panel). 
As for estimation of energy consumption four different sections were considered: mechanical treatment, solvent treatment of coarse fraction, leaching of fine fractions, and thermal treatment of coarse fraction.

For mechanical treatment an $11 \mathrm{~kW}$ crushing unit ensuring the treatment of about $400 \mathrm{~kg} / \mathrm{h}$ of panels was considered implying that $27.5 \mathrm{kWh}$ are consumed to treat $1,000 \mathrm{~kg}$ of panels.

For solvent treatment the estimation of energy consumption was performed considering stirring, heating, and recovery of solvent from polymeric residue by heating and condensation. These contributions were computed as follows:

- The energy required to sustain the agitation during solvent treatment was computed by taking into account that a $1.5 \mathrm{~kW}$ agitator motor was operated about $10 \mathrm{~min}$ (considering an intermittent use of stirring avoiding glass size reduction) during any solvent treatment batch. Considering that each batch of the pilot plant corresponds to the treatment of $47 \mathrm{~kg}$ of panels, a specific energy consumption of $5.3 \mathrm{kWh}$ was found per $1,000 \mathrm{~kg}$ of panels.

- Solvent treatment was performed at $50{ }^{\circ} \mathrm{C}$. The energy required to reach this temperature starting from $25^{\circ} \mathrm{C}$ was computed by taking into account the composition of the suspension which is made up of cyclohexane $(80 \% \mathrm{w} / \mathrm{w})$ and a solid mixture $(20 \% \mathrm{w} / \mathrm{w})$ made up of the glass fraction with size larger than $1 \mathrm{~mm}$, tedlar and EVA (Table 2). The specific heat of the solid mixture was then computed by summing the specific heats of glass, tedlar and EVA $\left(0.2,0.42,0.75 \mathrm{KJ} /\left(\mathrm{kg}^{*} \mathrm{~K}\right)\right)$, each of them multiplied by the corresponding weight fraction in the treated solid as derived from Table 2. Specific heat values of tedlar and EVA (Mark and Seidel, 2014) and glass (Parry's) were used giving specific heat of the solid as $c_{p, s o l i d}=1$ $\mathrm{KJ} /\left(\mathrm{kg}^{*} \mathrm{~K}\right)$. The specific heat of the suspension was then computed as $\mathrm{c}_{p}$, suspension $=0.8 \mathrm{c}_{\mathrm{p}, \text { cyhex }}$ $+0.2 c_{p, s o l i d}=1.7 \mathrm{~kJ} /\left(\mathrm{kg}^{\star} \mathrm{K}\right)$, where $c_{p, \text { cyhex }}=1.9 \mathrm{KJ} /\left(\mathrm{kg}^{\star} \mathrm{K}\right)$ is the specific heat of cyclohexane (Perry's, 1984). Considering the amount of suspension needed for treating $1 \mathrm{Kg}$ of EOL panel expressed as $M=$ suspension $\mathrm{Kg}$ per $\mathrm{kg}$ of panels $(M=2.4$ for polycrystalline, $M=2.7$ for amorphous and CdTe) the energy consumption can be estimated for treating $1,000 \mathrm{Kg}$ of the different panel types as $M \cdot c_{p, \text { suspension }} \cdot\left(T_{0}-T_{F}\right) \cdot 1,000 / 3,600$, where $T_{0}=25$ and $T_{F}=50{ }^{\circ} \mathrm{C}$. 
- The plastic material obtained from treatment with cyclohexane and successive separation of the glass fraction $(>1 \mathrm{~mm})$ is characterized by a cyclohexane content equal to about $q_{\text {cyhex }}=3 \mathrm{~kg}$ per $\mathrm{kg}$ of dry solid. Since $\mathrm{m}_{\text {poly }}=0.1 \mathrm{~kg}$ of dry plastic material per $\mathrm{kg}$ of treated panels is produced and the of cyclohexane vaporization enthalpy is $\Delta \mathrm{H}_{\mathrm{v}, \text { cyhex }}=380 \mathrm{~kJ} / \mathrm{kg}$ (Perry's Chemical engineers' Handbook. New York: McGraw-Hill, 1984), the energy required to achieve the vaporization of the cyclohexane absorbed by the plastic material is about $\mathrm{m}_{\text {poly }} \cdot \Delta \mathrm{H}_{\mathrm{v}, \text { cyhex }} \cdot \mathrm{q}_{\mathrm{cyhex}} \cdot 1,000 / 3,600=31.7 \mathrm{kWh}$ per $1,000 \mathrm{~kg}$ of treated panels. The cyclohexane must be then recovered by condensation, which requires taking back the vaporization heat $31.7 \mathrm{kWh}$ per $1,000 \mathrm{~kg}$ of treated panels. In practice, the vaporizationcondensation cycle can be effectively performed using a vacuum evaporator involving the application of heat pump. By assuming that the practical coefficient of performance (COP) (ratio between the heat power and the compression power) of the heat pump is 3 , the energy to recover the cyclohexane from EVA is about $31.7 / 3 \sim 10.6 \mathrm{kWh}$ per $1,000 \mathrm{~kg}$ of treated panels. Notice that the assumption of a COP equal to 3 represents an underestimation for this type of application (Chua et al., 2002; Chua et al., 2010).

The energy required to perform hydrometallurgical treatment of the glass fractions $(0.08-0.4 \mathrm{~mm})$ was determined by the agitation of the leaching suspension, heating of the leaching suspension to $60{ }^{\circ} \mathrm{C}$, and filtration of the leaching suspension. These contributions were computed as follows:

- The energy consumed by agitation was computed by taking into account a pilot reactor treating in each batch $400 \mathrm{~kg}$ suspension with 0.2 solid to liquid ratio ( $80 \mathrm{Kg}$ of fine fraction per batch), imposing the application of a $0.5 \mathrm{~kW}$ agitator for $3 \mathrm{~h}$. Considering the amount of fine fraction produced for each panel type for 1,000 Kg of EOL PVP (Table 2), an energy consumption ranging between 2.7 and $3.3 \mathrm{kWh}$ was estimated.

- The energy required to heat the leaching suspension was computed by assuming that heat losses are negligible, and that the leaching suspension is heated from 25 to $60^{\circ} \mathrm{C}$. Under those assumptions, energy consumption between 21 and $26 \mathrm{kWh}$ per 1,000 $\mathrm{kg}$ of panels was found. The estimation was done considering that the leaching suspension is composed 
of glass powder $(20 \% \mathrm{w} / \mathrm{w})$ and sulphuric acid $20 \%(80 \% \mathrm{w} / \mathrm{w})$, which gives a specific heat equal to $\left(0.2 c_{p, g l a s s}+0.8 c_{p}\right.$,liq $)=3.1 \mathrm{~kJ} /\left(\mathrm{kg}^{*} \mathrm{~K}\right)$, where $c_{p, \text { glass }}=0.8 \mathrm{KJ} /\left(\mathrm{kg}^{*} \mathrm{~K}\right)$ is the specific heat of glass, and $c_{p}$,liq $=3.62 \mathrm{KJ} /\left(\mathrm{kg}^{*} \mathrm{~K}\right)$ is the specific heat of the $20 \% \mathrm{w} / \mathrm{w}$ aqueous sulphuric acid solution (Perry's, 1984). These specific heat values refer to $298 \mathrm{~K}$ and they were verified to barely vary over the narrow temperature range of interest (Perry's, 1984).

- The energy required to perform filtration was computed by taking into account that filtration is enabled by the application of a filter press equipped with a $1.5 \mathrm{~kW}$ pump and it lasts about $0.33 \mathrm{~h}$. By following the approach illustrated to compute the contribution of agitation and heating to energy consumption (see two previous bullets), consumption around 1.0 $\mathrm{kWh}$ per $1,000 \mathrm{~kg}$ of panel can be found for filtration.

The computed energy consumptions account for the main energy losses in the process. Particularly, the energy consumptions by crushing and reactor agitation were taken into account by using the actual powers adsorbed by the crushing and the impeller motor during tests performed by the operation of a pilot plant with processing capacity of 200 tons of panels per year. Likewise, we assumed that the heating of the reactor solutions was performed by the application of an electric boiler, whose efficiency is between 95 and $100 \%$. The energy consumption by the vaporization-condensation cycle performed to recover the solvent from residual EVA was computed by means of an overall COP, underestimated compared to the COP values reported in the scientific literature and in the commercial description by suppliers, which already takes into account energy losses. Finally, dispersions of energy owing to the transfer of heat from the external surface of equipment are assumed to be negligible as reactors and pipes must be thermally insulated.

Other energy losses which can be estimated are those induced by the partial evaporation and aspiration of the hot liquid contained in the leaching reactor and by the need to heat not only the liquids and the solids charged to reactors but also the reactors and the connecting pipes. An estimation for these two energy losses was derived based on the designs of the solvent treatment and of the leaching reactor needed to sustain a processing capacity of 200 ton/y. For the purposes 
of the present study, the geometries of the two reactors were assumed to be cylindrical. We evaluated that the above mentioned processing capacity can be attained by using a jacketed solvent treatment reactor made of carbon steel and thermally insulated with volume equal to $250 \mathrm{~L}$ and weight equal to about $200 \mathrm{~kg}$, and a leaching reactor made of polypropylene with volume equal to $500 \mathrm{~L}$ and a weight around $83 \mathrm{~kg}$. The energy losses were then evaluated as follows:

- We computed the evaporation rate of water and sulfuric acid from the leaching solution by using the method detailed in Smith (2001). To this purpose, we used a velocity of the air above the liquid equal to $0.3 \mathrm{~m} / \mathrm{s}$. The temperature was fixed to $\mathrm{T}=60^{\circ} \mathrm{C}$. The evaporation rate of sulfuric acid was found to be negligible while a flux of evaporating water equal to $0.32 \mathrm{~mol} /\left(\mathrm{m}^{2} \mathrm{~s}\right)$ was determined. Multiplying this flux by the area of the liquid exposed to the atmosphere, which is the reactor section $\left(0.5 \mathrm{~m}^{2}\right)$, and by the vaporization enthalpy of water evaluated at $90{ }^{\circ} \mathrm{C}(2282.5 \mathrm{~kJ} / \mathrm{kg})$ gives $2395 \mathrm{~kJ} / \mathrm{h}$. By taking into account that the duration of a leaching batch is $3 \mathrm{~h}$, we then find an energy consumption of $7187 \mathrm{~kJ} / \mathrm{batch}$. Since 80 $\mathrm{kg}$ of solid are processed in a single leaching batch, corresponding to $0.143 \mathrm{~kg}$ of solid per $\mathrm{kg}$ of processed panels, an energy consumption of $3.6 \mathrm{kWh} / \mathrm{ton}$ of panels is found.

- The energy losses determined by the heating of reactors were computed by taking into account that the leaching reactor was made of polypropylene $\left(C_{p}\right.$ polypropylene $\sim 1.9$ $\mathrm{kJ} /(\mathrm{kg} \mathrm{K}))$ with a weight around $83 \mathrm{~kg}$ while the solvent reactor was made of carbon steel $\left(\mathrm{C}_{\mathrm{p}}\right.$ steel $\left.\sim 0.5 \mathrm{~kJ} /(\mathrm{kg} \mathrm{K})\right)$ with a weight around $200 \mathrm{~kg}$. By computing the heat necessary to bring the two reactors from the initial temperature of $25{ }^{\circ} \mathrm{C}$ to the final operating temperature $\left(50{ }^{\circ} \mathrm{C}\right.$ for solvent treatment reactor and $60^{\circ} \mathrm{C}$ for leaching reactor), and taking into account that $140 \mathrm{~kg}$ of suspension per batch are processed in the solvent treatment reactor corresponding to about $2.5 \mathrm{~kg}$ of suspension per $\mathrm{kg}$ of panels, and that $80 \mathrm{~kg}$ of solid are processed in a single leaching batch corresponding to $0.143 \mathrm{~kg}$ of solid per $\mathrm{kg}$ of panels, we have an overall energy loss equal to about $15 \mathrm{kWh} / \mathrm{ton}$ of panels.

The energy consumption imposed by the thermal treatment of the coarse fraction is due to heat that have to be supplied to achieve complete removal (gasification) of plastic (EVA, Tedlar). The 
energy required to remove plastics in the thermal treatment process is the sum of the heat required to bring the panel to the gasification temperature of plastic fraction and of the gasification heat of plastic fraction. The gasification temperature of EVA and Tedlar is about 435 and $475{ }^{\circ} \mathrm{C}$, respectively, the specific heat of glass, Tedlar and EVA is $0.2,0.45$ and $0.75 \mathrm{~kJ} /\left(\mathrm{Kg}^{*} \mathrm{~K}\right)$, respectively, and the gasification heat of EVA and Tedlar is between 1 and $2 \mathrm{MJ} / \mathrm{kg}$ (Mark and Seidel, 2014). This allows computing a specific energy consumption ranging between 95 and 106 $\mathrm{kWh} / \mathrm{Kg}$ of panels depending on the treated panel type.

An approximation for the energy losses in the thermal treatment was performed by assuming a rotary kiln with a thermal efficiency of $60 \%$ (Atmaca and Yumrutas, 2014). Starting from the computed energy consumption of $106 \mathrm{kWh} /$ ton of panels, which is determined by gasification and heating of the material, an energy loss of about $70 \mathrm{kWh} / \mathrm{ton}$ is determined.

\subsection{Process simulations}

Process simulations for the different routes (solvent or thermal options for coarse fractions) were performed varying the input parameters detailed in Table 3 (potentiality, EOLPVP fee, high-grade glass selling price, solvent make-up).

Some observations should be mentioned in order to explain the choices made in process simulations as detailed in the follow.

1) Potentiality of the plant: this input was chosen considering the estimation about waste projections made by Padoan et al.,(2019) using a distribution function for panel lifetime. According to these estimates, it is reasonable to assume that first plants operating in Italy during the next years will have potentiality of few thousands of tons of end of life panels. In particular, a low potentiality scenario of 3,000 ton/y was chosen corresponding to the year 2025-2031 (time range is due to different scenarios used in simulations of waste projections). Economic simulations were also performed at larger scale $(300,000$ ton/y) in order to assess profitability of the proposed process in the future (2030-2036), when larger amounts of wastes will have to be treated. 
2) Quality of glass: mass balances obtained for solvent and thermal options denoted very similar yields in glass, but the quality of the product is quite different due to the presence of a solid residue of combustion on the glass emerging from the thermal treatment (Figure S4). This residue is made up of carbon residues and metals as evidenced by XRF characterization (Table S2). Otherwise, the glass fraction from the solvent treatment appears clean from any residue (Figure S4). Specific analyses have been performed by the Experimental Station of Glass of Murano (Italy) in order to assess if this recovered glass was suitable for producing new panels. Glass samples from solvent treatment were characterized by XRF for chemical composition (Table S2) denoting the absence of metal residues. Also the size distribution was determined (Table S3) evidencing the absence of low-sized particles unsuitable for direct use in glass foundry (only $0.15 \%$ as weight is smaller than $1 \mathrm{~mm}$ ). Thermogravimetric analysis denoted the absence of organic residue with a weight loss lower than $0.25 \%$ after treatment at $550^{\circ} \mathrm{C}$ until constant weight. Finally, even the density was evaluated in order to ascertain the presence of high density particles, which can be deleterious during glass melting and flat panel production: even for this parameter the samples resulted suitable having only $0.01 \%$ weight with density larger than $2.9 \mathrm{~g} / \mathrm{cm}^{3}$. All the parameters addressed evidenced that recovered glass from solvent treatment can be reused as high-grade glass in the manufacturing of new flat panels. According to these data, low-grade glass classification is chosen for coarse glass from thermal treatment and high-grade glass for the coarse glass fraction emerging from solvent treatment. Fine glass fractions $(0.4-1 \mathrm{~mm})$ directly recovered after mechanical operation, due to the reduced size, are also included as low-grade glass in process simulations.

3) Recovery of metals from the fine fractions: a raw evaluation was made assuming mean content for metals in fine fractions $(0.67 \mathrm{mg} / \mathrm{g}$ for $\mathrm{Cu}, 1.1 \mathrm{mg} / \mathrm{g}$ for $\mathrm{Zn}, 3.2 \mathrm{mg} / \mathrm{g}$ for Al, 5.8 $\mathrm{mg} / \mathrm{g}$ for $\mathrm{Fe}$, and $0.01 \mathrm{mg} / \mathrm{g}$ per $\mathrm{Ag}$ ) and market price from the web (5.2 $€ / \mathrm{Kg}$ for $\mathrm{Cu}, 2.4$ $€ / \mathrm{Kg}$ for $\mathrm{Zn}, 1.5 € / \mathrm{Kg}$ for $\mathrm{Al}, 0.2 € / \mathrm{Kg}$ for $\mathrm{Fe}$, and $418 € / \mathrm{Kg}$ for $\mathrm{Ag}$ ) (https://www.dailymetalprice.com) with an optimistic 100\% recovery. For a plant with 3,000 
ton/y potentiality of EOLPVP, an annual income of less than $9,000 €$ could be obtained adding a section for metal recovery. From the same plant selling high-grade glass $(0.16-0.3$ $€ / \mathrm{Kg})$, aluminum scaps from the frames, and copper scraps from metallic filaments $(0.7$ $€ / \mathrm{Kg}$ and $2 € / \mathrm{Kg}$, respectively) (https://www.capitalscrapmetal.com/prices/) assuming $80 \%$ recovery for glass and $100 \%$ for $\mathrm{Al}$ and Cu scraps, would give an income of 560,000 $830,000 €$ per year depending on the glass price. At this stage, it does not seem reasonable adding a complete metal recovery section with these figures for the low potentiality of next 10 years. Then leaching of fine fractions can be done if metal impurities have to be reduced for specific application in cement or other building material preparation, in which they are diluted in primary charges. A different reasoning can be done for polymeric residues in which EVA, cells, and back sheet film are recovered together. In fact, due to the specific characteristics of the mechanical process (minimizing fine production) the majority of metals is inside this residue that is now under investigation for polymer separation and metal recovery. At this stage, the polymeric residue which is an output of the solvent route is not addressed as a product but as a waste without any fee for disposal due to its intrinsic metal content.

4) Cyclohexane recycle: during lab scale tests cyclohexane was reused in sequential cycles according to the procedure reported in materials and methods. Nevertheless, due to cyclohexane volatility it is was not possible evaluating a balance for this solvent due to the losses as vapour. When passing to large scale using cyclohexane will imply using confined reactors without any vapour loss. At this stage, we assumed that cyclohexane will be partially reintegrated with fresh solvent at any cycle with a make-up. The effect of varying the make-up was estimated at two values $(0.2$ and $2 \%)$ in process simulations.

5) EOLPVP fee: the EOL fee for PVP is additional revenue of the process including the price that should be paid for dismantling-collection-treatment by consortia of photovoltaic panels producers or end of life panels collectors according to EU directive. The range of variability of this input was evaluated considering the fee payed for collection, transport, and 
treatment by PVP owners to the Gestore Servizi Energetici (Manager of Energetic Services in Italy). This fee is variable depending on the year of installation ranging from 10 to $12 €$ for each panel; considering an average panel weight of $20 \mathrm{Kg}$, the fee corresponds to $0.5-0.6$ $€ / \mathrm{Kg}$. We managed to consider only $0.2,0.3$, and $0.4 € / \mathrm{Kg}$ for this fee because it include not only treatment but also collection and transport.

6) Estimates for operating costs related to the treatment of gas were taken from works related to fuel gas treatment in incinerating plants for wastes containing organics, plastics, and metals: these estimates presented great variability from $0.06 € / \mathrm{Kg}$ (Schneider et. al., 2010) to

$€ / \mathrm{Kg}$

(http://www.stefanomontanari.net/wpcontent/uploads/2008/09/images pdf inceneritore vie nna.pdf). Considering the high concentration of metals in the gas emissions from thermal treatment of panels (Tammaro et al., 2015) the range of variation of this cost was chosen in the range $0.15-0.2 € / \mathrm{kg}$.

7) High-value glass market price: preliminary market testing of glass samples produced by solvent treatment gave an estimate of $0.16 € / \mathrm{Kg}$ from a glass ware producer: due to the uncertainty of this value simulations were performed also at $0.2 € / \mathrm{Kg}$.

The economic feasibility of the process was estimated evaluating the PBT for the solvent process (Table 3) and the thermal process (Table 4) varying the input parameters according to the observations reported before. 


\begin{tabular}{|c|c|c|c|c|c|}
\hline $\begin{array}{l}\text { potentiality } \\
\text { (ton/y) }\end{array}$ & $\begin{array}{l}\text { fee } \\
(€ / \mathrm{Kg})\end{array}$ & $\begin{array}{l}\text { glass } \\
\text { price } \\
(€ / \mathrm{Kg})\end{array}$ & $\begin{array}{l}\text { cyclohexane } \\
\text { make-up } \\
(\%)\end{array}$ & $\begin{array}{l}\text { PBT } \\
\text { (year) }\end{array}$ & $\begin{array}{l}\text { PBT } \\
\text { change } \\
(\%)\end{array}$ \\
\hline $\mathbf{3 , 0 0 0}$ & $\mathbf{0 . 2}$ & $\mathbf{0 . 1 6}$ & $\mathbf{0 . 2}$ & $\mathbf{1 1 . 3 7}$ & - \\
\hline 3,000 & 0.3 & 0.16 & 0.2 & 6.95 & $-39 \%$ \\
3,000 & 0.4 & 0.16 & 0.2 & 5.02 & $-56 \%$ \\
3,000 & 0.3 & 0.2 & 0.2 & 6.36 & $-44 \%$ \\
3,000 & 0.2 & 0.16 & 2 & 23 & $102 \%$ \\
3,000 & 0.3 & 0.16 & 2 & 8.57 & $-25 \%$ \\
3,000 & 0.4 & 0.16 & 2 & 5.82 & $-49 \%$ \\
3,000 & 0.3 & 0.2 & 2 & 7.7 & $-32 \%$ \\
\hline 30,000 & $\mathbf{0 . 2}$ & $\mathbf{0 . 1 6}$ & $\mathbf{0 . 2}$ & $\mathbf{3 . 8 5}$ & - \\
\hline 30,000 & 0.3 & 0.16 & 0.2 & 2.7 & $-30 \%$ \\
30,000 & 0.4 & 0.16 & 0.2 & 2.8 & $-27 \%$ \\
30,000 & 0.3 & 0.2 & 0.2 & 2.52 & $-35 \%$ \\
30,000 & 0.2 & 0.16 & 2 & 4.81 & $25 \%$ \\
30,000 & 0.3 & 0.16 & 2 & 3.16 & $-18 \%$ \\
30,000 & 0.4 & 0.16 & 2 & 2.35 & $-39 \%$ \\
30,000 & 0.3 & 0.2 & 2 & 2.92 & $-24 \%$ \\
\hline
\end{tabular}

Table 3. Input parameters for process simulations of solvent treatment: base levels for each potentiality in bolt characters.

\begin{tabular}{|r|r|l|l|r|l|}
\hline $\begin{array}{l}\text { Potentiality } \\
\text { (ton/y) }\end{array}$ & $\begin{array}{l}\text { fee } \\
(€ / \mathrm{Kg})\end{array}$ & $\begin{array}{l}\text { glass } \\
\text { price } \\
(€ / \mathrm{Kg})\end{array}$ & $\begin{array}{l}\text { gas } \\
\text { treatment } \\
\text { 0.15 } € / \text { Kg }\end{array}$ & $\begin{array}{l}\text { PBT } \\
\text { (year) }\end{array}$ & $\begin{array}{l}\text { PBT } \\
\text { change } \\
\text { (\%) }\end{array}$ \\
\hline $\mathbf{3 , 0 0 0}$ & $\mathbf{0 . 2}$ & $\mathbf{0 . 0 5}$ & $\mathbf{0 . 1 5}$ & $\mathbf{2 5}$ & - \\
\hline 3,000 & 0.3 & 0.05 & 0.15 & 8.73 & $-65 \%$ \\
3,000 & 0.4 & 0.05 & 0.15 & 5.89 & $-76 \%$ \\
3,000 & 0.2 & 0.05 & 0.2 & 27.67 & $11 \%$ \\
3,000 & 0.3 & 0.05 & 0.2 & 8.87 & $-65 \%$ \\
3,000 & 0.4 & 0.05 & 0.2 & 5.95 & $-76 \%$ \\
\hline $\mathbf{3 0 , 0 0 0}$ & $\mathbf{0 . 2}$ & $\mathbf{0 . 0 5}$ & $\mathbf{0 . 1 5}$ & $\mathbf{5 . 2 9}-$ & \\
\hline 30,000 & 0.3 & 0.05 & 0.15 & 3.35 & $-37 \%$ \\
30,000 & 0.4 & 0.05 & 0.15 & 2.45 & $-54 \%$ \\
30,000 & 0.2 & 0.05 & 0.2 & 5.4 & $2 \%$ \\
30,000 & 0.3 & 0.05 & 0.2 & 3.39 & $-36 \%$ \\
30,000 & 0.4 & 0.05 & 0.2 & 2.47 & $-53 \%$ \\
\hline
\end{tabular}

Table 4. Input parameters for process simulations of thermal treatment: base levels for each potentiality in bolt characters. 
As for solvent treatment, considering the lowest potentiality $(3,000$ ton/y) and the lowest levels for both EOL fee and glass price, a PBT larger than 10 years was obtained which makes the process economically unsustainable. Keeping all the parameters fixed and increasing the EOL fee to 0.3 and then $0.4 € / \mathrm{Kg}$ determined a significant reduction of PBT to 7 and $5 \mathrm{y}$, respectively. These results denoted that at least in the first years the economic support from consortia is needed to make sustainable the investment for EOL PVP treatment.

Even the final market price of glass is a key parameter in final PBT: considering EOL fee of 0.3 $€ / \mathrm{Kg}$, the increase of glass price to $0.2 € / \mathrm{Kg}$ determined a reduction of PBT of $44 \%$ (6.4 y).

Another important input in process feasibility was the make-up of solvent in each cycle: simulations showed that increasing this input from 0.2 to $2 \%$ determined a dramatic increase of the PBT $(+100 \%)$. Make-up effect can be buffered increasing the EOL fee or the glass price: then with $2 \%$ make-up $0.4 € / \mathrm{Kg}$ EOL fee and 0.16 glass price the PBT is lower than $6 \mathrm{y}$.

Increasing the potentiality to 30,000 ton/y the process profitability increases significantly and even working at the base levels the PBT falls to $3.8 \mathrm{y}$. Positive effects of increasing EOL fee and glass price give \% variation of PBT lower than in the case of 3,000 ton/y which is more sensitive to input changes.

Also the thermal treatment resulted unsustainable for 3,000 ton/y potentiality and the lowest EOL fee. Increasing the EOL fee to $0.4 € / K g$ greatly improved the economic figure. The effect of the cost of gas treatment seems to have a not relevant effect on the overall economic of the process. The increase of potentiality to 30,000 ton/y greatly improved the PBT of the process as for the case of the solvent process.

Comparing solvent and thermal treatment in the base conditions for both potentialities solvent process presented lower values of the PBT than the thermal one for both potentialities evidencing an economic advantage mainly due to the recycling of high-grade glass. 


\section{$3.5 \quad$ LCA}

The performed LCA had the general goal to compare the different technologies considered in the present work, highlighting the most critical environmental aspects for each kind of photovoltaic panel. The mechanical crushing was not reported within the results, because it was not significant, if compared to the other process steps (with an impact between 0.5 and $5 \%$ of the whole normalized and weighted impact). Overall, as showed in Figure 6, the solvent treatment option represents the best choice, from an environmental point of view, in most of the considered categories. The main advantage is the possibility to recover the solar glass (high-grade glass), with a higher intrinsic value than the glass cullet (low-value glass) recovered from the thermal treatment, able to balance the environmental load connected with the solvent use. Nevertheless, the negative effect of the cyclohexane use is particularly evident in the climate change category, which represents the only category in which the thermal option has better result than solvent one. The reason can be found in the solvent treatment that produces around $400 \mathrm{~kg} \mathrm{CO}$-Equiv, irrespective of the panel kind (Figure 6b). The main contributions which cause this significant environmental load are: the cyclohexane production (55\% of the total emission) and the treatment of the produced organic wastewater (about 35\%).

LCA estimates (made considering $0.5 \%$ make-up) confirmed the sensitiveness of solvent process to chemical consumption which should be minimized as possible.

On the other hand, the impact due to the hydrometallurgical process is evident in the categories of human toxicity, both non-cancer and cancer, where more than $90 \%$ is due to the resulting wastewater treatment. The combination of solvent and hydrometallurgical steps justifies the comparable results (solvent vs thermal processes) achieved in the category of human toxicity, (non-cancer effects Figure 6e). Significant differences between the panel types are mainly due the possibility of the aluminum frame recovery in the polycrystalline Si panel, which represents between the 50 and $80 \%$ of the whole environmental credit, on the selected category basis. 


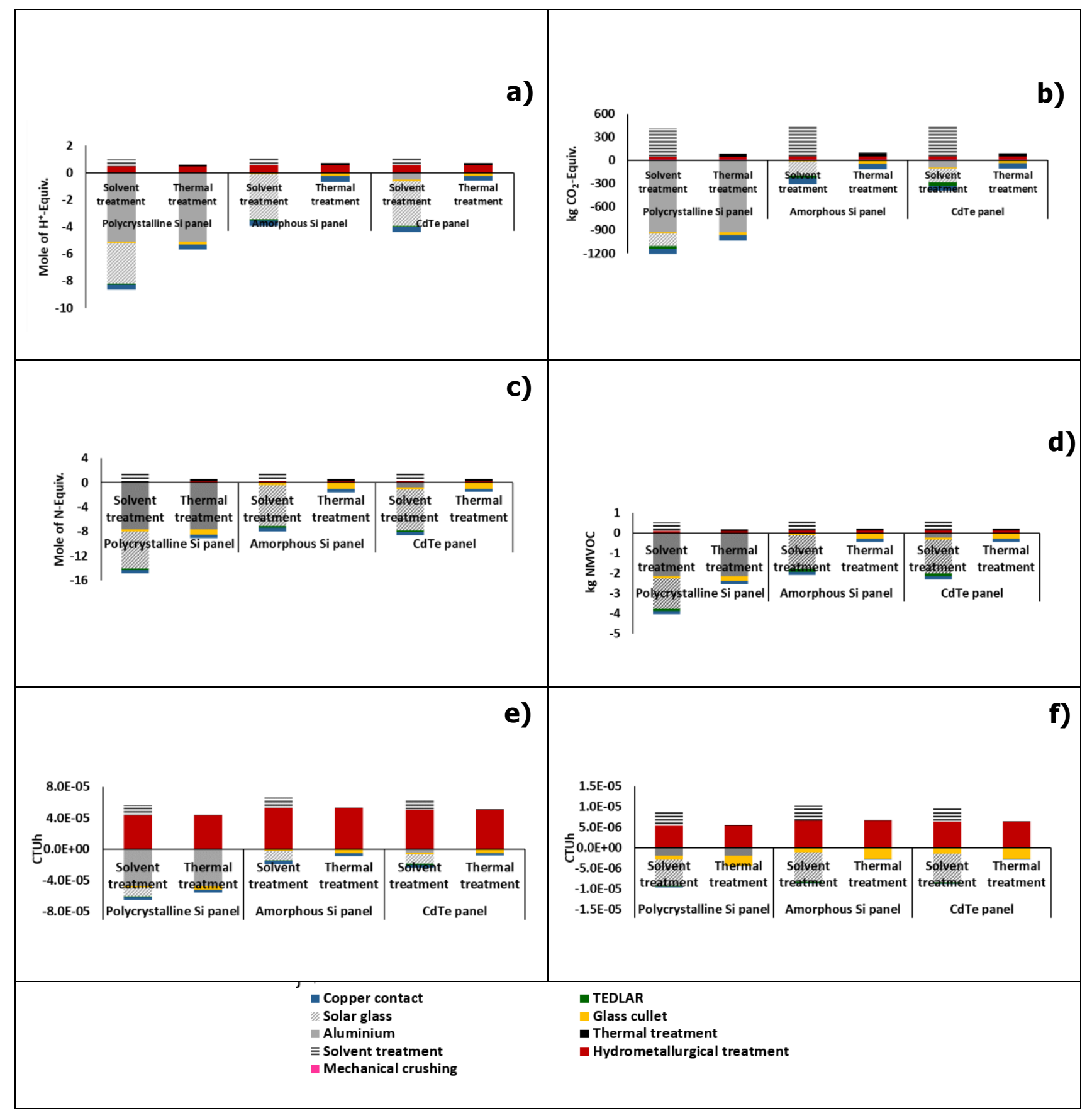

Figure 6. Estimation of the environmental impacts generated by the two considered scenarios of solvent and thermal treatments, in the categories of: a) acidification, b) climate change, c) terrestrial eutrophication, d) photochemical ozone formation e) human toxicity, non-cancer effects, f) human toxicity, cancer effects (Functional unit: 1,000 kg of end-of-life panel). 
The normalization and weighting of data allowed to express the general impact of the considered technologies and to make a comparison between the two possible treatments, as showed in Figure 7. As a whole, an average credit of 0.8 for the solvent treatment was estimated, compared to a credit of 0.2 for the thermal treatment, thanks to the possibility of the double quality glass recovery, further combined with the aluminum frame exploitation, in the polycrystalline Si panel case. Focusing on the solvent processes impact, the pie chart intends to clarify the main responsible steps for the environmental load associated to the treatment, showing average values for the three panels. It is evident that the main environmental load is due to the treatment of organic wastewaters, which represent about the $90 \%$ of the total impact, followed by the cyclohexane production.

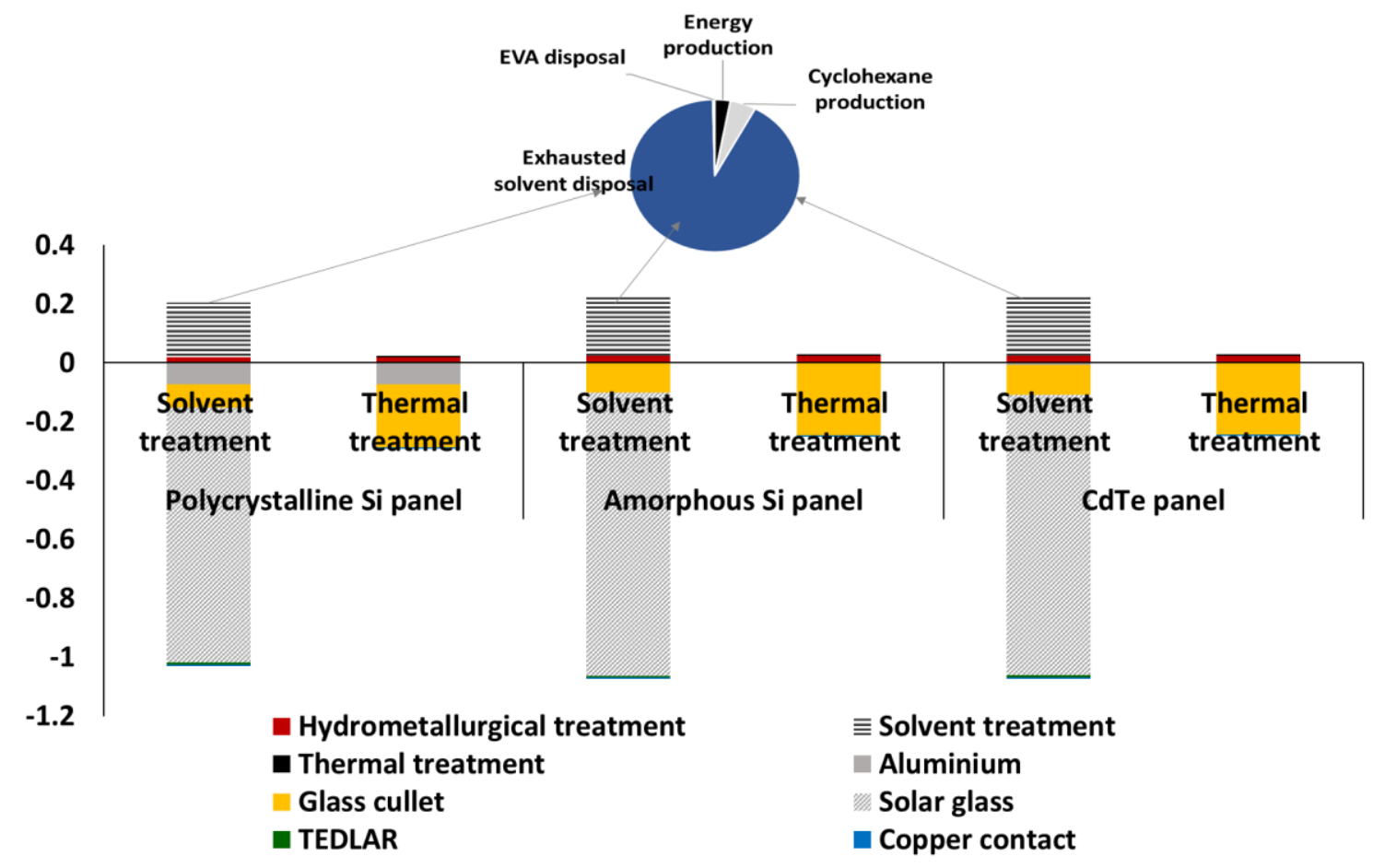

Figure 7. Normalized and weighted environmental impacts of PV panels recycling: solvent vs. thermal treatment (functional unit $1,000 \mathrm{~kg}$ of end-of-life photovoltaic panel). The pie chart represents the specific contributions on the environmental impact within the solvent treatment. 
Considering the relevance of the climate change impact category, the comparison between the panel primary production and the glass recycling by the solvent treatment, allowed an additional assessment of the process sustainability. Notably, the environmental load due to the panel recycling is quite low (2-10\%) if compared to production (Figure S5 in Supplementary Material). However, it can be observed that the use of recycled solar glass, at the point of substitution, can provide an advantage in the impact of primary production up to the $10 \%$, in the case of $\mathrm{CdTe}$ panel.

\section{CONCLUSIONS}

In this work, an integrated mechanical and chemical process was presented including automatic crushing of panels, solvent treatment of the coarse fraction, and leaching of fine fractions. Main products of the process are high-value glass $(>1 \mathrm{~mm})$ from solvent treatment of the coarse fraction, and low-value glass from fine fractions.

Automatic crushing was performed in a way that production of fine fraction is minimized in order to obtain the maximum yield of high-value glass and minimize the low-value glass of fine size $(<1$ $\mathrm{mm})$.

Solvent treatment of the coarse fraction allowed complete detachment of the different components in $1 \mathrm{~h}$ at $50^{\circ}$ under stirring: this kinetic is significantly higher than others reported in the literature (Doi et al., 2001), in which solvent is generally used for cell recovery (using panel fragment of the cell size, i.e. $12-15 \mathrm{~cm}$ ), and requires even days for complete detachment.

This difference can be explained considering the mechanism of dissolution/swelling of the encapsulant by the solvent: reducing the size of the sample decreases the time needed to the solvent to penetrate the polymeric matrix, thus favoring the kinetics of detachment. Then, if the kinetics of solvent treatment for cell recovery seems to be quite low in comparison with thermal treatment (1h) (Kang et al., 2012), when treating fragments of $1-2 \mathrm{~cm}$ this difference is not relevant. Glass recovered from solvent treatment presented quality standard superior than that from thermal treatment. Dedicated tests to assess the quality of recycled glass from solvent treatment denoted 
the suitability of the samples as raw materials for the production of new PVP. On the other side the glass from thermal treatment presented a superficial residue of metals making it unsuitable for direct use in foundry.

Preliminary economic analysis of solvent process evidenced the profitability at low potentiality $(3,000$ ton/y) only if EOL fee is available for EOL treatment operators; increasing the scale the effect of this input is less relevant. A relevant aspect emerged from process simulation is the sensitivity of the PBT on the solvent consumption especially for low potentiality, evidencing that also according to environmental constrains almost all the solvent used should be recycled in the plant.

Process analysis was performed without considering metal recovery from fine fractions of glass because according to the specific mechanical treatment crushed samples presented limited amount of fines and the majority of metal remained in the coarse fraction, and then after solvent treatment, in the polymeric residue. This residue was not considered for exploitation in this work because further investigations are in course aiming at the separation of the different plastics (Tedlar from EVA) and the metal recovery. Considering the peculiar characteristics of the mechanical treatment (avoiding fine formations in which metallic fragments of cells generally accumulate), this polymeric fraction is the one in which most of the metallic values are concentrated.

Even without considering metal recovery, process simulations denoted that solvent treatment is sustainable for 30,000 ton/y potentiality. In the case of low potentiality, EOL fee is a necessary help in sustaining PVP treatment. Using the same inputs, solvent treatment presents lower PBT than thermal treatment. Even considering Life Cycle Assessment solvent process impacts are positive with respect to thermal one mainly due to the high value recycled glass.

Mechanical approach (e.g. crushing and sorting) is currently commercialised in Europe for EOL PVP: after fine grinding, metals are recovered from glass particles by physical processes (IEA, 2018). Nevertheless, glass recovered from such processes is a low-grade product due to the reduced size, and the contamination of metals and organics. 
The proposed process was a valid alternative to conventional physical treatment fulfilling both recycling targets of the Directive 2012/19/EU and also promoting high-value recycling according to CENELEC EN50625-2-4 guidelines.

Acknowledgement: The research is part of the PhotoLife project (LIFE13 ENV/IT/001033) cofinanced by EU LIFE+ program. Supported was also received by CNPq (Process 202624/2015-3).

\section{References}

Akimoto, Y., lizukab, A., Shibata, E., 2018. High-voltage pulse crushing and physical separation of polycrystalline silicon photovoltaic panels. Miner. Eng. 125, 1-9

Amato, A., Rocchetti, L., Beolchini, F., 2017. Environmental impact assessment of different end-oflife LCD management strategies. Waste Manage. 59, 432-441.

Atmaca, A., Yumrutas, R., 2014. Analysis of the parameters affecting energy consumption of a rotary kiln in cement industry. Appl. Therm. Eng 66, 435-444.

Azeumo, M. F., Germana, C., Ippolito, N. M., Franco, M., Luigi, P., Settimio, S., 2019. Solar Energy Materials and Solar Cells Photovoltaic module recycling, a physical and a chemical recovery process. Sol. Energ. Mater. Sol. C. 193, 314-319.

Bigum, M., Brogaard, L., Christensen, T.H., 2012. Metal recovery from high-grade WEEE: A life cycle assessment. J. Hazard. Mater. 207-208, 8-14.

Bio Intelligence Service, 2011. Study on photovoltaic panels supplementing the impact assessment for a recast of the WEEE directive Final Report 14 April 2011. <http://ec.europa.eu/environment/waste/weee/pdf/Study\%20on\%20PVs\%20Bio\%20final.pdf>.

Blieske U., Stollwerck, G., 2013. Glass and other encapsulation materials, in Willeke, G.P., Weber, E.R. (Eds.), Semiconductors and semimetals Advances in Photovoltaics: part 2. Elsevier, USA, pp 200-254.

Butler, J.H., Hooper, P., 2011. Glass Waste, Waste. Elsevier Inc. https://doi.org/10.1016/B978-012-381475-3.10011-7 
Castellani, V., Benini, L., Sala, S., Pant, R., 2016. A distance-to-target weighting method for Europe 2020. Int J Life Cycle Assess. 14044, 1159-1169.

CENELEC (European Committee for Electrotechnical Standardization), EN50625-2-4 Collection, logistics \& treatment requirements for WEEE - Part 2:Treatment requirements for photovoltaic panels, Final Draft, CENELEC TC111X WG6, November 2016, Brussels, Belgium.

Chua, K.J., Chou, S.K., Yang, W.M., 2010. Advances in heat pump systems: A review. Appl. Energ. 87, 3611-3624.

Chua, K.J., Chou, S.K., Ho, J.C., Hawlader, M.N.A., 2002. Heat pump drying: recent developments and future trends Dry. Technol. 20, 1579-1610

Desideri, U., Proietti, S., Zepparelli, F., Sdringola, P., Bini, S., 2012. Life Cycle Assessment of a ground-mounted $1778 \mathrm{kWp}$ photovoltaic plant and comparison with traditional energy production systems. Appl. Energ. 97, 930-943.

Dias, P., Veit, H., 2019. Recycling Crystalline Silicon Photovoltaic Modules chapter 3 in Emerging photovoltaic materials: Silicon \& Beyond Edited by Santosh K. Kurinec Rochester Institute of Technology, NY, USA Wyley ISBN 978-1-119-40754-6.

Doi, T., Tsuda, I., Unagida, H., Murata, A., Sakuta, K., Kurokawa, K., 2001. Experimental study on PV module recycling with organic solvent method, Sol. Energ. Mat. Sol. C. 67, 397-403.

Doni, A., Dughiero, F., 2012. Electrothermal Heating Process Applied to c-Si PV Recycling. In: 38th IEEE Photovoltaic Specialists Conference, 757-762.

Duflou, J.R., Peeters, J.R., Altamirano, D., Bracquen, E., Dewulf, W., 2018. Demanufacturing photovoltaic panels: comparison of end-of-life treatment strategies for improved resource recovery, CIRP Annals - Manufacturing Technology 67, 29-32

Frisson, L., Lieten, K., Bruton, T., Declercq, K., Szlufcik, J., De Moor, H., Goris, M., Benali, A., Aceves O., 2000. Recent Improvements in Industrial PV Module Recycling. In: 16th European Photovoltaic Solar Energy Conference, Glasgow, UK. 
Fraunhofer Institute for Solar Energy Systems, Photovoltaic Report, Freiburg, 14 March 2019 https://www.ise.fraunhofer.de/content/dam/ise/de/documents/publications/studies/Photovoltaics-

\section{$\underline{\text { Report.pdf }}$}

Gerbinet, S., Belboom, S., Leonard, A., 2014. Life Cycle Analysis (LCA) of photovoltaic panels: A review. Renew. Sust. Energ. Rev. 38, 747-753.

Giacchetta, G., Leporini, M., Marchetti, B., 2016. Evaluation of the environmental benefits of new high value process for the management of the end of life of thin film photovoltaic modules. J. Clean. Prod. 51, 214-224.

Goetzberger, A., Hebling, C., Schock, H.W., 2003. Photovoltaic materials, history, status and outlook, Materials Science and Engineering Report 40, 1-46.

Gustafsson, A.M.K., Foreman, M. R.S.J., Ekberg, C., 2014. Recycling of high purity selenium from CIGS solar cell waste materials. Waste Manage. 34, 1775-1782.

Gustafsson, A.M.K., Steenari, B., Ekberg, C., 2015. Recycling of CIGS Solar Cell Waste Materials: Separation of Copper, Indium, and Gallium by High-Temperature Chlorination Reaction with Ammonium Chloride, Sep. Sci, Technol. 50, 2415-2425.

Hao H.C., Lin, K.L., Wang, D.Y., Chao S.J., Shiu, H.S., Cheng, T.W., Hwang, C.L., 2012. Recycling of solar panel waste glass as a partial replacement of metakaolinite in the production of geopolymers. The Open Civil Engineering Journal 6, 239-248.

Iannicelli-Zubiani, E.M., Giani, M.I., Recanati, F., Dotelli, G., Puricelli, S., Cristiani, C., 2016. Environmental impacts of a hydrometallurgical process for electronic waste treatment: A life cycle assessment case study. J. Clean. Prod. 140, 1204-1216.

IEA (International Energy Agency) Photovoltaic Power Systems Program, End-of-Life Management of Photovoltaic Panels: Trends in PV Module Recycling Technologies IEA PVPS Task12, Subtask 1, Recycling Report IEA-PVPS T12-10: 2018 January 2018 ISBN 978-3-906042-61-9

International Reference Life Cycle Data System (ILCD), 2010. General guide for Life Cycle Assessment-Detailed guidance. European Commission, Joint Research Centre (DG 
JRC).<http://lct.jrc.ec.europa.eu/assessment/assessment/publications>

(last

accessed 21.09.2016).

IRENA (International Renewable Energy Agency) and International Energy Agency (IEA), 2016. End-of-life management: Solar photovoltaic

panels. https://www.irena.org/publications/2016/Jun/End-of-life-management-Solar-Photovoltaic-Panels IRENA (International Renewable Energy Agency), 2017. Renewable Power Generation Costs in 2017. https://www.irena.org/publications/2018/Jan/Renewable-power-generation-costs-in-2017

Ito, M., Komoto, K., Kurokawa, K., 2010. Life-cycle analyses of very-large scale PV systems using six types of PV modules. Curr. Appl. Phys. 10, S271-S273. https://doi.org/10.1016/j.cap.2009.11.028

Kim, H., Cha, K., Fthenakis, V.M., Sinha, P., Hur, T., 2014. Life cycle assessment of cadmium telluride photovoltaic (CdTe PV) systems. Sol. Energy 103, 78-88. https://doi.org/10.1016/j.solener.2014.02.008

Larsen, A.W., Merrild, H., Christensen, T.H., 2009. Recycling of glass: Accounting of greenhouse gases and global warming contributions. Waste Manag. Res. 27, 754-762.

Leccisi, E., Raugei, M., Fthenakis, V., 2016. The energy and environmental performance of ground-mounted photovoltaic systems - A timely update. Energies 9. https://doi.org/10.3390/en9080622

Jung, B., Park, J., Seo, D., Park, N., 2016. Sustainable System for Raw-Metal Recovery from Crystalline Silicon Solar Panels: From Noble-Metal Extraction to Lead Removal. ACS Sustain. Chem. Eng. 4, 4079-4083.

Kang, S., Yoo, S., Lee J., Boo, B., Ryu, H., 2012. Experimental investigations for recycling of silicon and glass from waste photovoltaic modules. Renew. Energ. 47, 152-159.

Kim, H., Cha, K., Fthenakis, V. M., Sinha, P., Hur, T., 2014. Life cycle assessment of cadmium telluride photovoltaic (CdTe PV) systems. Sol. Energy. 103, 78-88.

Kim, Y., Lee, J., 2012. Dissolution of ethylene vinyl acetate in crystalline silicon PV modules using ultrasonic irradiation and organic solvent. Sol. Energy Mat. Sol. Cells 98, 317-322. 
Koch, S., Nieschalk, D., Berghold, J., Wendlandt, S., Krauter, S., Grunow, P., 2012. Potential induced degradation effects on crystalline silicon cells with various antireflective coatings. Proc. 27th Eur. Photovoltaic Solar Energy Conf. Exhib., Frankfurt, Germany, pp. 1985-1990

Kushiya, K., Ohshita, M., Tanaka, M., 2003. Development of Recycling and Reuse Technologies for Large-area $\mathrm{Cu}(\operatorname{InGa}) \mathrm{Se}_{2}$-Based Thin-film Modules. In: $3^{\text {rd }}$ World Conference on Photovoltaic Energy Conversion, 1892-1895.

Lin, K.L., Chu, T.C., Cheng, C.J., Lee, C.H., Chang, T.C., Wang, K.S., 2012. Recycling solar panel waste glass sintered as glass-ceramics. Environ. Prog. Sustain. 31(4) DOI: 10.1002/ep.10587 Latunussa, C.E.L., Ardente, F., Blengini, G.A., Mancini L., 2016. Life Cycle Assessment of an innovative recycling process for crystalline silicon photovoltaic panels. Sol. Energy Mat. Sol. Cells, $156,101-111$.

Manfredi, S., Allacker, K., Pelletier, N., Chomkhamsri, K., de Souza, D. M., 2012. Product environmental footprint (PEF) guide.

Mark, H. F., Seidel, A., 2014. Encyclopedia of Polymer Science and Technology, Wiley and Sons, 4th edition.

Menikpura, S.N.M., Santo, A., Hotta, Y., 2014. Assessing the climate co-benefits from Waste Electrical and Electronic Equipment (WEEE) recycling in Japan. J. Clean. Prod. 74, 183-190.

Padoan, F.C.S.M., Altimari, P., Pagnanelli, F., 2019). Recycling of end of life photovoltaic panels: A chemical prospective on process development. Solar Energy 177, 746-761.

Pagnanelli, F., Moscardini, E., Granata, G., Abo Atia, T., Altimari, P., Havlik, T., Toro, L., 2017. Physical and chemical treatment of end of life panels: An integrated automatic approach viable for different photovoltaic technologies. Waste Manage. 59, 422-431.

Paiano, A., 2015. Photovoltaic waste assessment in Italy. Renew. Sust. Energ. Rev. 41, 99-112.

Peeters, J. R., Altamirano, D., Dewulf, W., Duflou, J. R., 2017. Forecasting the composition of emerging waste streams with sensitivity analysis: A case study for photovoltaic (PV) panels in Flanders, Resources, Conserv. Recy. 120, 14-26. 
Peng, J., Lu, L., Yang, H., 2013. Review on life cycle assessment of energy payback and greenhouse gas emission of solar photovoltaic systems. Renew. Sust. Energ. Rev. 19, 255-274.

Perry's Chemical engineers' Handbook. New York: McGraw-Hill, 1984

Prado, P.F.A., Tenório, J.A.S., Espinosa, D.C.R., 2017. Alternative Method for Materials Separation from Crystalline Silicon Photovoltaic Modules. In: Zhang L. et al. (eds) Energy Technology 2017. The Minerals, Metals \& Materials Series. Springer, Cham

Raugei, M., Fullana-i-Palmer, P., Fthenakis, V., 2012. The energy return on energy investment (EROI) of photovoltaics: Methodology and comparisons with fossil fuel life cycles. Energ. Policy 45, $576-582$.

Rocchetti, L., Beolchini, F., 2015. Recovery of valuable materials from end-of-life thin-film photovoltaic panels: environmental impact assessment of different management options. J. Clean. Prod. 89, 59-64.

Schneider, D.R., Loncar, D., Bogdan, Z., 2010. Cost Analysis of Waste-to-Energy Plant, Strojarstvo 52 (3) 369-378.

Sherwani, A.F., Usmani, J.A., Varun, 2010. Life cycle assessment of solar PV based electricity generation systems: A review. Renew. Sust. Energ. Rev. 14, 540-544.

Smith, R.L., 2001. Predicting evaporation rates and times for spills of chemical mixtures. Ann. Occup. Hyg. 45, 437-445.

SolarPower Europe, 2017. Global Market Outlook for Solar Power 2017-2021. http://www.solarpowereurope.org

Sopian, K., Cheow, S. L., Zaid, S.H., 2017. An overview AIP Conference Proceedings 1877, 020004 https://doi.org/10.1063/1.4999854

Stamford, L., Azapagic, A., 2018. Environmental Impacts of Photovoltaics: The Effects of Technological Improvements and Transfer of Manufacturing from Europe to China. Energy Technol. 6, 1148-1160. https://doi.org/10.1002/ente.201800037

Stoppato, A., 2008. Life cycle assessment of photovoltaic electricity generation. Energy 33, 224232. 
Tammaro, M., Rimauro, J., Fiandra, V., Salluzzo, A., 2015. Thermal treatment of waste photovoltaic module for recovery and recycling: Experimental assessment of the presence of metals in the gas emissions and in the ashes. Renew. Energ. 81, 103-112.

Toro, L., Pagnanelli, F., Granata, G., Moscardini, E., 2016. Process for treating spent photovoltaic panels. Patent EP 2997169 A1.

Valenzano, F., Nappi, P., Consiglio, M., 2000. ANPA Piemonte I rifiuti del comparto agricolo Tipologie e coefficienti di produzione.

Wang, T., Hsiao, J., Du, C., 2012. Recycling of Materials from Silicon Base Solar Cell Module. In: 38th IEEE Photovoltaic Specialists Conference, 2355-2358.

Weinfurtner, J., 1996. Recycling insulating and/or laminated glass panels. Patent DE 4418573 C1. Xie, M., Ruan, J., Bai, W., Qiao, Q., Bai, L., Zhang, J., Li, H., Lv, F., Fu, H., 2018. Pollutant payback time and environmental impact of Chinese multi-crystalline photovoltaic production based on life cycle assessment. J. Clean. Prod. 184, 648-659. https://doi.org/10.1016/j.jclepro.2018.02.290

Yi, Y. K., Kim, H. S., Tran, T., Hong, S. K., Kim, M. J., 2014. Recovering valuable metals from recycled photovoltaic modules, J. Air Waste Manage. Assoc. 64, 797-807.

Zampori, L., Saouter, E., Schau, E., Castellani, V., Sala, S., 2016. Guide for interpreting assessment result life cycle EUR 28266 EN; doi:10.2788/ 
